\title{
Biodegradable ionic liquids: Part I. Concept, preliminary targets and evaluation
}

\author{
Nicholas Gathergood ${ }^{a b}$ M. Teresa Garcia*c and Peter J. Scammells*a \\ a Department of Medicinal Chemistry, Victorian College of Pharmacy, Monash University, \\ Parkville 3052, Australia. E-mail: peter.scammells@vcp.monash.edu.au; Fax: +61 03 \\ 99039582; Tel: +610399039542 \\ b School of Biological and Chemical Sciences, Deakin University, Geelong 3217, Australia. \\ E-mail: nicholas.gathergood@vcp.monash.edu.au \\ c Department of Surfactant Technology, IIQAB-CSIC, Jordi Girona 18-26, 08034, Spain. \\ E-mail: mtgbet@iiqab.csic.es; Fax: +34 93204 5904; Tel: +34 934006100
}

Received 25th November 2003, Accepted 16th January 2004

First published as an Advance Article on the web 4th February 2004

\begin{abstract}
The design, preparation and evaluation of biodegradable ionic liquids containing ester or amide groups in the alkyl side chain are presented. Factors improving the biodegradation of surfactants were successfully applied to ionic liquids. These novel ionic liquids can be prepared from readily available starting materials in high yield. The introduction of a group susceptible to enzymatic hydrolysis greatly improves the biodegradation (OECD 301D 'Closed Bottle Test') compared with the commonly used dialkylimidazolium ionic liquids, bmimBF 4 and bmimPF$_{6}$. For the

3-methyl-1-(alkyloxycarbonylmethyl)imidazolium bromide series, the greatest biodegradation was observed when alkyl

= butyl, pentyl, hexyl and octyl. The corresponding amide analogs proved to be poorly biodegradable.
\end{abstract}

\section{Introduction}

Ionic liquids (ILs) have been the subject of considerable interest as media for a wide range of synthetic and analytical processes. ${ }^{1,2}$ They are considered in a 'green chemistry' context due to their low vapour pressure, ease of recovery facilitating recycling ${ }^{3}$ and applicability to catalytic processes. ${ }^{4}$ ILs possess a number of interesting properties such as high polarity and ionic conductivity, a wide window of electrochemical potential and excellent chemical and thermal stability. However, it is this stability that has lead us to question the potential for ILs to accumulate in the environment. ${ }^{5}$ When the ionic liquid has served its operational use, disposal becomes an issue. As the pressure to reduce incineration and landfill waste increases the requirement for chemicals which are biodegradable increases. ${ }^{6}$ Within the field of green chemistry it is unacceptable to produce large quantities of waste which have high ecotoxicity or biological activity. ${ }^{7}$ Seddon reported the first industrial process where ionic liquids were used on a multi-tonne scale. ${ }^{8}$ As ionic liquids advance from academic curiosities the need to study their toxicity and biodegradation is paramount.

Toxicity to humans and other organisms has obvious significance, while toxicity to micro organisms has the potential to limit biodegradation. Like biodegradability, the assessment of IL toxicity is only now being addressed. There have been a few articles stating that there is a need to test the biodegradation of ionic liquids ${ }^{5}$ however experimental results to ascertain these properties have been surprisingly lacking.

In a preliminary communication ${ }^{9}$ we reported the first investigation into the biodegradability of the dialkylimidazolium ionic liquids. We chose the dialkylimidazolium ILs as a starting point and incorporated features which have been found to improve the biodegradability of other classes of compounds such as surfactants. Since this initial disclosure of our findings no biodegradation data on ILs has been published, although a few preliminary toxicology results have been reported.

Jastorff and co-workers subsequently reported a theoretical environment risk analysis on a test set of dialkylimidazolium ILs. ${ }^{10}$ This multidimensional analysis was based on five ecotoxicological indicators; release, spatiotemporal range, bioaccumulation, biological activity and uncertainty. The current lack of detailed experimental data on the biodegradability of ILs complicated predictions on bioaccumulation and spatiotemporal range and resulted in a high uncertainty level.

Our inspiration for this work came from the development of biodegradable surfactants. We now report our progress towards preparing a readily biodegradable ionic liquid.

\section{History of surfactants}

The development of biodegradable surfactants ${ }^{11}$ has been of significant commercial interest since the 1940's when synthetic surfactants were developed as a replacement for soap in many laundry products. Tetrapropylene alkyl benzene sulfonates (TPBS) ${ }^{12}$ were manufactured extensively but due to their poor biodegradation lead to major problems in sewage treatment and contamination of river waters. ${ }^{13}$

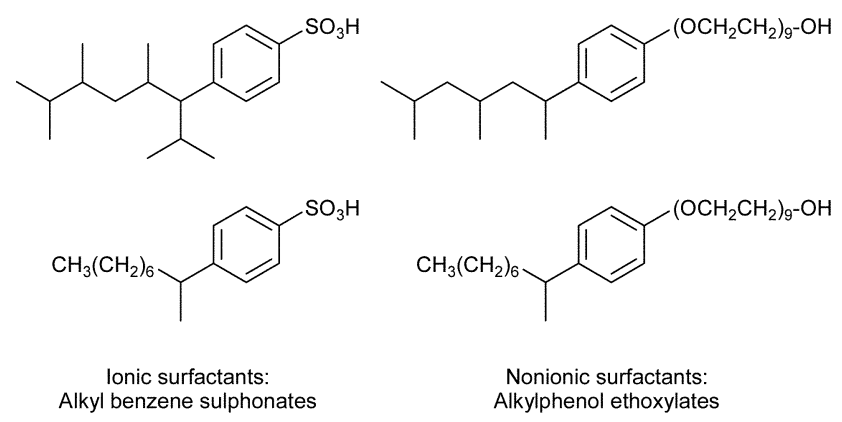

Modification of the highly branched alkyl chain to the linear secondary alkyl group gave linear alkylbenzene sulfonate surfactants (LAS) with greatly improved biodegradation. ${ }^{14}$ In the 1960's TPBS were phased out and replaced with LAS in the United States. ${ }^{12}$

On further examination of the literature regarding biodegradation of surfactant compounds we noticed a close resemblance between many quaternary ammonium compounds as well as surfactants based around an imidazolium core. These derivatives have a striking resemblance to the structure of many of the most important ILs prepared to date and we felt that much of the work developing biodegradable surfactants would be relevant to the design of a biodegradable ionic liquid. In particular is the development of biodegradable surface active quaternary ammo- 
nium compounds (QACs). The most popular QAC used initially was the dialkyl dimethyl ammonium salt (1), however the biodegradation of $\mathbf{1}$ in aquatic sediments is low and this coupled to its ecotoxicity has led to its replacement by dialkyl QACs based on the imidazolium and ethoxylated ethanaminium QACs (compounds 2 and 3). ${ }^{15}$ The presence of the amide bonds led to improved biodegradation properties due to an extra hydrolysis degradation pathway. Ester derivatives (4 and $\mathbf{5}$ ) and related compounds have also been prepared and show good biodegradation. ${ }^{15,16 c}$
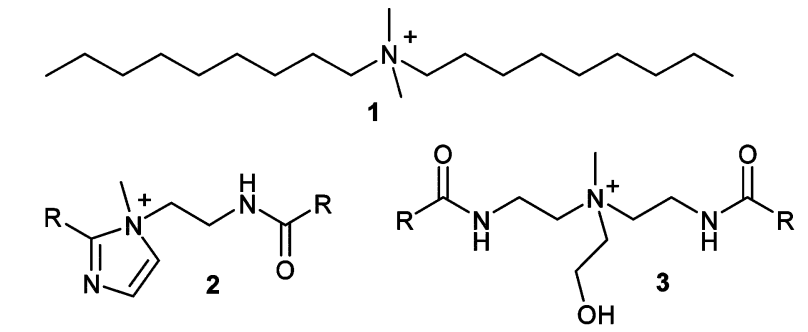<smiles>[R]C(=O)OCC[N+](C)(CCO)CCOC([R])=O</smiles>

$\mathrm{R}=$ long linear alkyl chain e.g. $\mathrm{C}_{14} \mathrm{H}_{29}$

\section{Design}

Boethling 15 identified three factors which are important in the design of biodegradable compounds; (i) the presence of potential sites of enzymatic hydrolysis (for example, esters and amides), (ii) the introduction of oxygen in the form of hydroxyl, aldehyde or carboxylic acid groups, and (iii) the presence of unsubstituted linear alkyl chains (especially $\geq 4$ carbons) and phenyl rings, which represent possible sites for attack by oxygenases. These principles have been followed during the development of biodegradable surfactants. $16-18$

Not all of these structural features are appropriate for ILs. The incorporation of oxygen containing functional groups such as alcohols, aldehyde and carboxylic acids would severely limit the ILs usefulness as reaction media, while the introduction of phenyl groups is known to produce compounds with elevated melting points. ${ }^{19}$ As a result, we chose to prepare dialkylimidazolium ILs with ester or amide functionality in one of the side chains. It was deemed important to limit branching in the side chains so only linear alkyl groups attached to the ester and amide were chosen. An important feature of this design is that although there are a very large number of possible ionic liquids that can theoretically be prepared based on the imidazolium core, within the limits suggested in the design segment of this paper, the number of potential hot targets is reasonably small. The incorporation of an ester or amide group was postulated to be a balance between reduced chemical stability and increased biodegradability.

A major concern at the design stage of this project was the physical properties of these modified imidazolium ionic liquids. Points which needed to be addressed were 1) melting points and 2) solubility and the effect of the ester/amide alkyl length on these properties. If the inclusion of an ester or amide bond into the side chain lead to increased order and crystallinity these target ionic liquids would only be liquids at elevated temperatures. A key property of $\mathrm{PF}_{6}$ and $\mathrm{NTf}_{2}$ based ILs is their hydrophobic nature. If the hydrogen bonding possible with the ester or amide in the side chain was sufficient to remove this hydrophobic character then their use as alternatives for $\mathrm{BmimPF}_{6}$ and $\mathrm{BmimNTf}_{2}$ would be compromised.

\section{Results and discussion}

Syntheses of the ILs described in this manuscript were based on standard approaches for the preparation of imidazolium ILs. 19,20 This process involved alkylation of methyl imidazole with the appropriate ester or amide derivative of bromoacetic acid.

The esters or amide derivatives of bromoacetic acid were either commercially available or formed in one step via the reaction of bromoacetyl bromide with the appropriate alcohol or amine. ${ }^{21}$ An advantage of this route is that a wide range of ester and amide side chains can be prepared easily. For ionic liquids with anions other than bromide, a metathesis reaction was employed to introduce the counter ion of choice (Scheme 1). Metathesis of the halide anion to

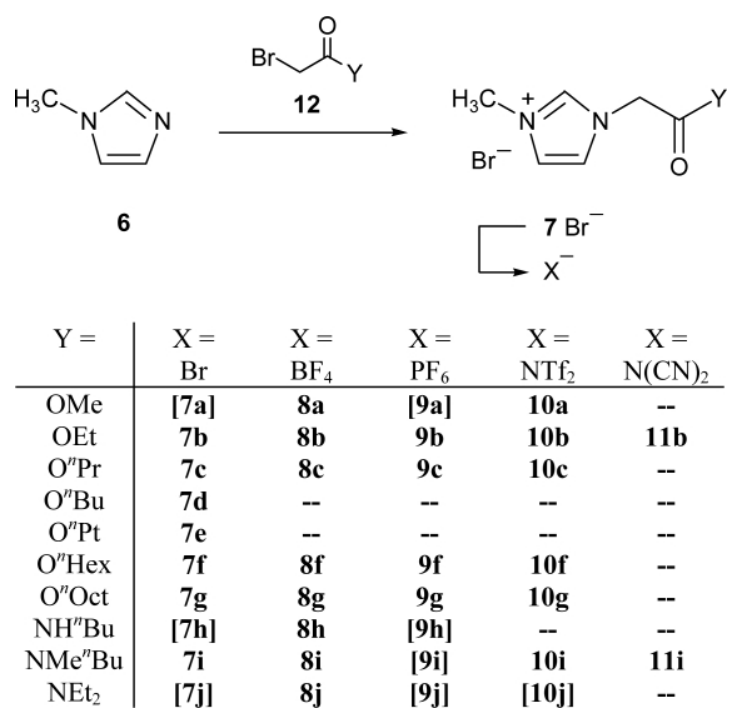

Scheme 1 IL synthesis [compounds in parentheses are solids at room temperature].

$\mathrm{BF}_{4}{ }^{-}, \mathrm{PF}_{6}{ }^{-}, \mathrm{NTf}_{2}{ }^{-}$and $\mathrm{N}(\mathrm{CN})_{2}{ }^{-}$proceeded in good to excellent yield. $\mathrm{BF}_{4}-$ ionic liquids were prepared by counter-ion exchange with $\mathrm{NaBF}_{4}$ in acetonitrile. Removal of the solvent gave IL contaminated with trace $\mathrm{NaBF}_{4}$ as shown by ${ }^{19} \mathrm{~F}$ NMR. Clean samples could be isolated after a simple work-up. Compound $\mathbf{9 h}$ was prepared by counter-ion exchange with $\mathrm{KPF}_{6}$ in acetonitrile. $\mathrm{PF}_{6}{ }^{-}$and $\mathrm{NTf}_{2}-$ based ionic liquids (except 9 h) were prepared by mixing an aqueous solution of the bromide salt with $\mathrm{KPF}_{6}$ or LiNTf $_{2}$, respectively. The hydrophobic IL phase was separated, washed and residual water removed under high vacuum to give pure samples. $\mathrm{N}(\mathrm{CN})_{2}-$ ionic liquids were prepared by counter-ion exchange with $\mathrm{NaN}(\mathrm{CN})_{2}$ in acetonitrile analogously to the $\mathrm{BF}_{4}{ }^{-}$ ionic liquid examples. ${ }^{22}$

Imidazolium salts with ester containing side chains were generally found to be liquids a room temperature; 21 of the 23 ester containing compounds proved to be liquids at room temperature, though compound $\mathbf{8 a}$ and all ILs with the bromide counter ion were viscous at room temperature. ILs with amide containing side chains were less likely to be room temperature ionic liquids; 6 of the 12 examples prepared were solids at room temperature. The secondary amide derivatives $7 \mathrm{~h}$ and $\mathbf{9 h}$ were solids, presumably due to increased intermolecular forces resulting from H-bonding. Imidazolium salts with $N, N$-diethyl amide side chains (compounds $\mathbf{7 j}, \mathbf{9 j}$ and $\mathbf{1 0 j}$ ) were solids, while $N$-butyl- $N$-methyl amides (compounds 7i, 8i, 10i, 11i) were liquids at room temperature.

There are two main features of the $N$-butyl- $N$-methyl amides (7i11i) which affect their macroscopic properties. Firstly, the unsymmetrical environment around the nitrogen of the amide ( $c f$. with solid $N, N$-diethyl amide examples $\mathbf{7} \mathbf{j}, \mathbf{9 j}$ and $\mathbf{1 0 j}$ ), as symmetry has previously been reported as important regarding melting point. ${ }^{1,23}$ Secondly, the $N$-butyl- $N$-methyl amides (7i-11i) prepared exist as a $1: 1.3$ mixture of rotomers around the amide bond and it 
is proposed that this isomeric mixture leads to a depression of the melting point. ${ }^{24}$

All the ionic liquids prepared in this paper have melting points below $100{ }^{\circ} \mathrm{C}$, a benchmark which has been set to determine their classification as ILs. ${ }^{8}$

All $\mathrm{PF}_{6}$ and $\mathrm{NTf}_{2}$ ILs containing an ester or amide in the side chain were hydrophobic except for the secondary amide derivative 9h. The introduction of the polar functional group did not significantly affect the water solubility of the IL. The use of $\mathrm{PF}_{6}$ ionic liquids outside of the research laboratory has been questioned due to their propensity to evolve HF if not stored and handled carefully. ${ }^{5 c}$ The authors note that for the ionic liquids presented within, HF formation would lead to decomposition. The $\mathrm{PF}_{6}$ ILs were prepared to study their properties however their suitability as industrial chemicals seems limited.

\section{Biodegradation testing data}

Two samples (7b and $\mathbf{8 b}$ ) were evaluated in a commercial laboratory ${ }^{25}$ using a modified Sturm test (OECD 301B). In this test, the chemical being evaluated is added to aerobic aqueous medium inoculated with wastewater micro organisms and the evolution of $\mathrm{CO}_{2}$ is measured for a defined period and reported as a percentage of the theoretical maximum. The Organisation for Economic Cooperation and Development (OECD) has approved this modified Sturm test as one means of assessing biodegradability. ${ }^{26} \mathrm{Com}-$ pounds which evolve more than $60 \%$ of the total $\mathrm{CO}_{2}$ are considered to be a pass (OECD 301B). This test was applied to two dialkylimidazoles with ester containing side chains (compounds $\mathbf{7 b}$ and $\mathbf{8 b}$ ) and bmimPF bll $_{6}$ Allree examples appeared to be relatively close to the pass level $\left(\mathbf{7 b}=48 \%, \mathbf{8 b}=59 \%\right.$ and bmimPF $_{6}=$ $60 \%$ ). After these preliminary results a more comprehensive biodegradation study was initiated.

A larger panel of ionic liquids with functionalised side chains were evaluated using the 'Closed Bottle Test' (OECD 301D). ${ }^{27}$ In this test the IL was added to an aerobic aqueous medium inoculated with wastewater micro organisms and the depletion of dissolved molecular oxygen was measured for a defined period of time and reported as a percentage of the theoretical maximum. Duplicate bottles of each series were analysed at the start of the test for dissolved oxygen and the remaining bottles were incubated at 20 ${ }^{\circ} \mathrm{C} \pm 1{ }^{\circ} \mathrm{C}$ in the dark. Bottles of all series were withdrawn in duplicate for dissolved oxygen analysis over the 28-day incubation period. A control with inoculum, but without test chemicals was run in parallel for the determination of oxygen blanks. Sodium ndodecyl sulfate (SDS) was used as reference substance. Compounds which reached a biodegradation level higher than $60 \%$ are referred to as readily biodegradable. Readily biodegradable has been defined as "an arbitrary classification of chemicals which have passed certain specified screening tests for ultimate biodegradability; the conditions in these tests are so stringent - relatively low density of non-acclimatized bacteria, relatively short duration, absence of other compounds - that such chemicals will rapidly and completely biodegrade in aquatic environments under aerobic conditions". ${ }^{11}$

The data showed significant differences between the biodegradability of the ionic liquids incorporating an ester group and those containing an amide linker in the side chain. ILs incorporating different alkyl esters (from methyl to octyl) in the side chain presented similar biodegradation profiles (Fig. 1).

It appears that the biodegradation increased slightly with increasing alkyl chain length for the lowest alkyl esters and later remained relatively constant (Fig. 2). Regarding the structure of ionic liquids containing an ester group in the chain side, it seems reasonable that the biodegradation of these molecules may be initiated by enzymatic cleavage of the ester bond leading to the separation of the imidazolium fragment and the corresponding primary alcohol that can readily be metabolized via the pathway of fatty acid $\beta$-oxidation. ${ }^{17}$

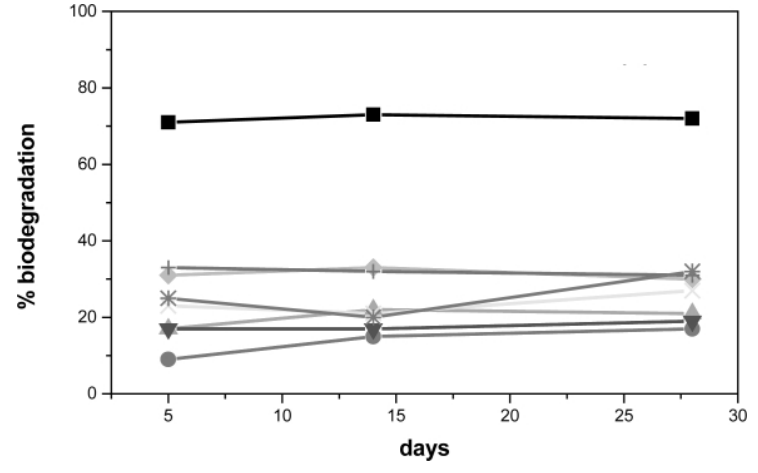

Fig. 1 Biodegradation curves of the ionic liquids containing an ester group in the cation side chain (3-methyl-1-(alkyloxymethylcarbonyl)-imidazolium bromides): $\operatorname{Me}(\boldsymbol{\bullet})$, Et $(\boldsymbol{\Delta}), \operatorname{Pr}(\boldsymbol{\nabla}), \mathrm{Bu}(\bullet)$, Pent $(+)$, Hex $(\times)$, Oct $(*)$; reference substance: SDS $(\mathbf{\square})$.

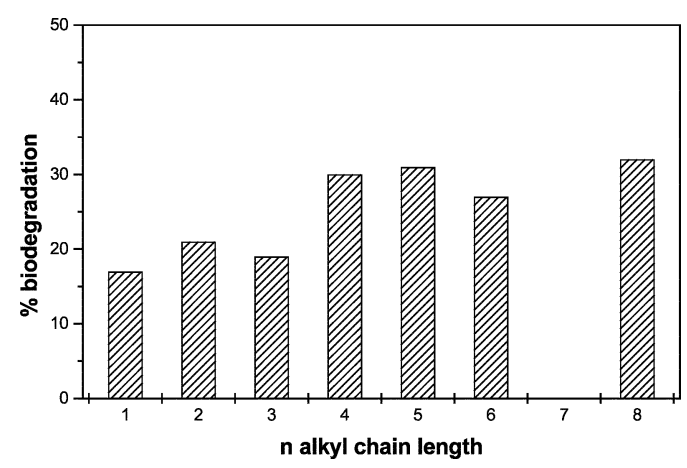

Fig. 2 Biodegradation (28-day period) of 3-methyl-1-(alkyloxycarbonylmethyl)imidazolium bromides as a function of the number of carbon atoms of the alkyl chain.

No evidence for some extent of ultimate biodegradation was detected for ILs containing an amide linker in the side chain (Fig. $3)$.

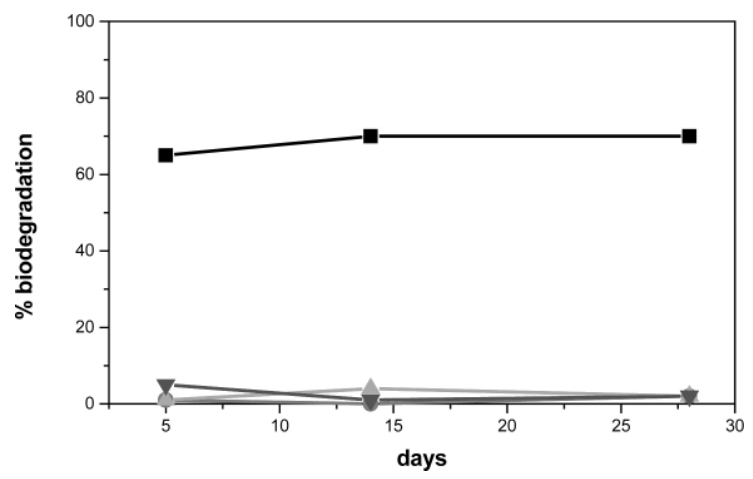

Fig. 3 Biodegradation curves of ionic liquids incorporating an amide group in the cation side chain: $\mathrm{N}\left(\mathrm{Et}_{2}\right)(\boldsymbol{O}), \mathrm{N}(\mathrm{BuH})(\boldsymbol{\Delta}), \mathrm{N}(\mathrm{BuMe})(\boldsymbol{\nabla})$; reference substance: SDS (

The two most widely used ionic liquids in academia and industry are based on the 1-n-butyl-3-methylimidazolium core. i.e. bmimBF$_{4}$ and bmimPF $_{6}$. These ILs, with bmimBr, were also tested for biodegradation by the 'Closed Bottle Test' (OECD 301D). $\mathrm{BmimBF}_{4}$ and bmim $\mathrm{PF}_{6}$ were found to show no biodegradation $(0 \%)$ in this test. BmimBr was found to have negligible biodegradation as measured by the Closed Bottle Test (1\%). Comparison of compounds $\mathbf{7 a - j}$ and bmimBr shows that the incorporation of the ester functional group has greatly improved the biodegradation properties of the IL. A more detailed study of counter-ion effect on biodegradation is in progress.

The results obtained from the Closed Bottle Test differed from those obtained using the modified Sturm test, with the latter 
indicating higher levels of biodegradation. Such differences may be related to the inoculum that was used. Biodegradation is intimately bound up with bacterial growth, nutrition and metabolism, and factors which affect these bacterial functions will also affect the biodegradability assessments. The nature and quantity of the inoculum play an important role in biodegradability assessment; the inoculum is probably the biggest single factor in the success of the batch test. Although the Closed Bottle and modified Sturm test have a number of similarities, the inoculum cell densities in these tests methods vary considerably (Closed Bottle Test; $10^{1}-10^{3}$ cells $\mathrm{mL}^{-1}$, modified Sturm test; $10^{4}-10^{6}$ cells $\mathrm{mL}^{-1}$ ). The bacterial cell density in the medium determines, to a large extent, the length of the lag period and also whether sufficient test substance is degraded within the duration of the test. If the number of cells capable of degrading the test substance is relatively high, the density will soon reach a value which makes a significant reduction in the concentration of the substance. However, when the initial cell density is relatively low, the lag period before a significant density is reached may be longer than the period of the test ( 28 days). Thus, the large differences found in the extent of ultimate biodegradation applying these two biodegradation methods could be reasonably attributed to significant variability in cell density.

The biodegradation data should be interpreted with caution taking into account the features both of the biodegradation test applied as well of the chemicals studied. Screening methods have been used in many studies on the biodegradability of quaternary ammonium compounds, namely surfactants such as alkyltrimethyl ammonium salts and benzylalkyldimethyl ammonium salts. ${ }^{28,29}$ It has been found that degradation rates of these compounds in screening methods significantly underestimated the rate and the extent of degradation occurring in natural environmental systems. ${ }^{30,31}$ Since imidazolium compounds are similarly charged ammonium ion-species similar results would be expected.

The toxicity of the ionic liquids may also have an negative impact on their biodegradation. Many quaternary ammonium salts are potential biocides and could inhibit growth of micro organisms capable of degrading quaternary ammonium salts. ${ }^{32-35}$ Ranke et al. ${ }^{36}$ recently conducted the first comprehensive study on the biological effects of dialkylimidazolium ionic liquids. Cytoxic effects of IL were determined against two mammalian cell lines (the promyeloctic leukaemia rat cell line IPC-18 and the rat glioma cell line (6) while acute toxicity was measured using a luminescent bacteria (Vibrio fischeri) assay. In general the toxicity of the ILs was found to be some orders of magnitude lower than that of the conventional solvents such as acetone, acetonitrile, methanol and methyl tert-butyl ether. The length of the alkyl chains was found to influence the toxicity of the dialkylimidazolium ILs, with longer chain lengths proving to be more toxic. A search of the literature shows that the biological properties of these biocides is related to their long alkyl chain length. 37,38

The anti-microbial activity of a series of 3-alkoxymethyl1-methylimidazolium ionic liquids $\left(\mathbf{1 3}, \mathrm{R}=\mathrm{C}_{3} \mathrm{H}_{7}-\mathrm{C}_{16} \mathrm{H}_{33}, \mathrm{X}=\right.$ $\mathrm{Cl}, \mathrm{BF}_{4}, \mathrm{PF}_{6}$ ) has also been investigated. ${ }^{37}$ ILs with shorter alkoxy substituents lacked activity against cocci, rods and fungi, while those with longer alkoxy chains ( $>10$ carbon atoms) proved to be very active. These findings have implications for the use of such IL as media for biotransformations as well as their degradation by micro organisms. A study of soft antimicrobials including 1-[(ndodecanoyloxy)methyl]-3-methylimidazolium chloride (14) by Bodor et al. showed that the long chain ester derivatives of methyl imidazole (including 14) show effective antimicrobial activity at ppm concentrations. ${ }^{39}$ Similarly, other alkyl substituted imidazolium compounds (e.g. 15) have also been found to possess biological activity. 40

Therefore, the biodegradation results found could be related to the inhibitory effects of the quaternary ammonium salts on the bacterial populations. In light of these results, further investigations on biodegradability and potential toxicity of ionic liquids should be carried out.

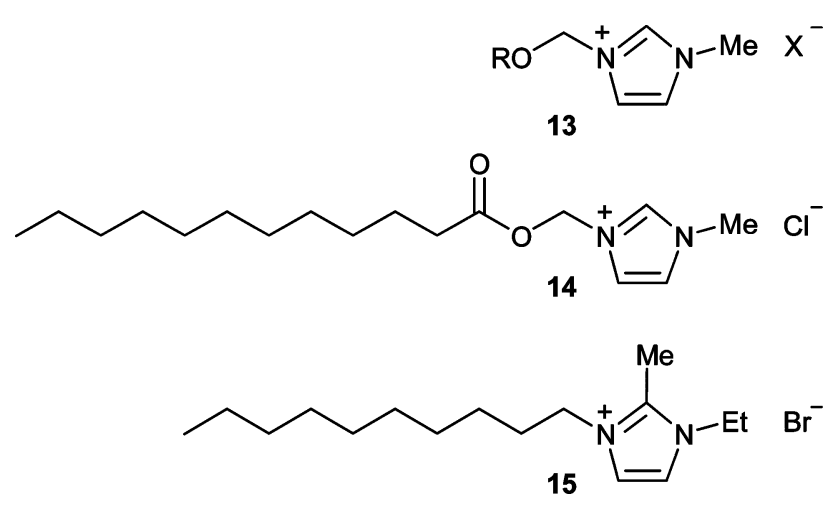

\section{Conclusions}

ILs containing an ester in the side-chain were generally found to be liquids at room temperature, independent of the counter-ion. The amide derivatives were solids at room temperature except for the $N$ butyl- $N$-methyl series. $\mathrm{NTf}_{2}$ and $\mathrm{PF}_{6}$ ILs containing an ester in the side chain exhibited the same hydrophobic character as bmimNTf ${ }_{2}$ and bmimPF$_{6}$.

The Bmim derived ILs and examples containing an amide in the side chain were found to show poor to negligible biodegradation as measured by the Closed Bottle Test (OECD 301D). The incorporation of an ester in the side chain resulted in a significant increase in biodegradation. Esters of type 7 with an alkyl chain length of $\geq 4$ proved to be the most biodegradable. It is postulated that this improved biodegradation is due in part to an enzymatic hydrolysis step which initiates a pathway to further breakdown products. Significant enhancement in the biodegradation of methylimidazolium ILs has been achieved. The factors which improved the biodegradation of surfactants have successfully been applied to ionic liquids.

\section{Experimental}

Methyl bromoacetate, ethyl bromoacetate, propyl bromoacetate were purchased from Aldrich and used without further purification. Butyl bromoacetate, pentyl bromoacetate, hexyl bromoacetate, octyl bromoacetate, $N, N$-diethyl-2-bromo-acetamide, $N$-butyl2-bromoacetamide and $N$-butyl- $N$-methyl-2-bromoacetamide were prepared as described below, and purified by distillation. Ethyl chloroacetate was purchased from Fluka and used without further purification. 1-Methylimidazole (99\%, Aldrich) was distilled before use to remove impurities detrimental to all ILs prepared. All organic solvents were dried and distilled before use. ILs were washed with distilled water. 3-Methyl-1-(methoxycarbonylmethy1)imidazolium bromide (3a) was prepared according to the literature $\left[\mathrm{mp}=131-133{ }^{\circ} \mathrm{C}\right] .{ }^{19} 1-n$-Butyl-3-methylimidazolium $\mathrm{BF}_{4}, \mathrm{PF}_{6}$ and $\mathrm{NTf}_{2}$ were prepared according to the literature. All NMR spectra of ILs were recorded in $\mathrm{CD}_{3} \mathrm{CN}$ (Aldrich 15,180-7, 99.8 atom \%D) on a Bruker Avance DPX 300 spectrometer. ${ }^{1} \mathrm{H}$ and ${ }^{13} \mathrm{C}$ NMR spectra were recorded at $300 \mathrm{MHz}$ and $75.4 \mathrm{MHz}$ respectively. NMR spectra of the ester and amide derivatives of bromoacetic were recorded in $\mathrm{CDCl}_{3}$. Melting points are uncorrected. All room temperature ionic liquids were placed in the fridge $\left(2^{\circ} \mathrm{C}\right)$ and freezer $\left(-18{ }^{\circ} \mathrm{C}\right)$ to further evaluate their melting points. Unless indicated in the experimental data below (see $\mathbf{8 g}$ and 9g) all the room temperature ionic liquids did not crystallise at -18 ${ }^{\circ} \mathrm{C}$. However, the viscosity of the ionic liquids at this temperature was significantly increased. A study of glass transition temperatures was not attempted with these materials. Determination of the physical properties of the ionic liquids prepared is still in progress (e.g. solubility, thermal stability, viscosity, density and stability to hydrolysis ${ }^{41}$ ) and will be reported in due course. 


\section{3-Methyl-1-(ethoxycarbonylmethyl)imidazolium bromide} (7b)

To a stirred solution of 1-methylimidazole $(4.1 \mathrm{~g}, 4.0 \mathrm{~mL}, 50 \mathrm{mmol})$ in THF $(50 \mathrm{~mL})$ at $-5^{\circ} \mathrm{C}$ under a nitrogen atmosphere was added dropwise ethyl bromoacetate $(10.0 \mathrm{~g}, 6.7 \mathrm{~mL}, 60 \mathrm{mmol})$. The reaction mixture was stirred vigorously at $-5^{\circ} \mathrm{C}$ for $1 \mathrm{~h}$, then at $\mathrm{rt}$ for $3 \mathrm{~h}$. The THF top phase was decanted and the IL washed with diethyl ether $(3 \times 10 \mathrm{~mL})$, then residual solvent removed in vacuo. The product was dried at $60{ }^{\circ} \mathrm{C}$ at $0.01 \mathrm{mmHg}$ for $72 \mathrm{~h}$ to give a clear viscous hygroscopic oil in $98 \%$ yield $(12.2 \mathrm{~g}, 49 \mathrm{mmol}) .{ }^{1} \mathrm{H}$ NMR (300 MHz, CD 3 CN) $9.38(\mathrm{~s}, 1 \mathrm{H}), 7.64(\mathrm{~s}, 1 \mathrm{H}), 7.51(\mathrm{~s}, 1 \mathrm{H})$, $5.30(\mathrm{~s}, 2 \mathrm{H}), 4.23(\mathrm{q}, J=7.0 \mathrm{~Hz}, 2 \mathrm{H}), 3.93(\mathrm{~s}, 3 \mathrm{H}), 1.25(\mathrm{t}, J=7.0$ $\mathrm{Hz}, 3 \mathrm{H}) .{ }^{13} \mathrm{C}$ NMR $(75 \mathrm{MHz}) \delta 167.80,138.72,124.82,124.10$, 63.23, 51.06, 37.40, 14.63. MS (ESI): $m / z, 169.1\left[\mathrm{M}-\mathrm{Br}^{-}\right]^{+}$; MS (ESI): $m / z, 79$ and $81\left[\mathrm{Br}^{-}\right]$.

\section{3-Methyl-1-(propoxycarbonylmethyl)imidazolium bromide (7c)}

This compound was prepared analogously to $7 \mathbf{b}$ using 1-methylimidazole $(2.11 \mathrm{~g}, 2.05 \mathrm{~mL}, 25 \mathrm{mmol})$ and propyl bromoacetate $(5.46$ $\mathrm{g}, 3.90 \mathrm{~mL}, 30 \mathrm{mmol})$ to give a clear viscous hygroscopic oil in $96 \%$ yield $(6.31 \mathrm{~g}, 24 \mathrm{mmol}) .{ }^{1} \mathrm{H} \mathrm{NMR}\left(300 \mathrm{MHz}, \mathrm{CD}_{3} \mathrm{CN}\right) \delta 9.57(\mathrm{~s}$, $1 \mathrm{H}), 7.78(\mathrm{~s}, 1 \mathrm{H}), 7.63(\mathrm{~s}, 1 \mathrm{H}), 5.42(\mathrm{~s}, 2 \mathrm{H}), 4.10(\mathrm{q}, J=7.0 \mathrm{~Hz}$, $2 \mathrm{H}), 3.94(\mathrm{~s}, 3 \mathrm{H}), 1.62(\mathrm{tq}, J=7.0,7.0 \mathrm{~Hz}, 2 \mathrm{H}), 0.89(\mathrm{t}, J=7.0$ $\mathrm{Hz}, 3 \mathrm{H}) .{ }^{13} \mathrm{C}(75 \mathrm{MHz}) \delta 167.93,138.89,124.81,124.40,68.73$, 51.08, 37.40, 22.68, 10.75. MS (ESI): $\mathrm{m} / \mathrm{z}, 183.1 \mathrm{M}^{\left.\mathrm{M}-\mathrm{Br}^{-}\right]^{+} \text {; MS }}$ (ESI): $m / z, 79$ and $81\left[\mathrm{Br}^{-}\right]$.

\section{3-Methyl-1-(butoxycarbonylmethyl)imidazolium bromide (7d)}

This compound was prepared analogously to $7 \mathbf{b}$ using 1-methylimidazole $(3.86 \mathrm{~g}, 3.75 \mathrm{~mL}, 47 \mathrm{mmol})$ in diethyl ether $(50 \mathrm{~mL})$ and butyl bromoacetate $(11.0 \mathrm{~g}, 56.4 \mathrm{mmol})$ to give a clear viscous hygroscopic oil in $98 \%$ yield $(12.75 \mathrm{~g}, 47 \mathrm{mmol}) .{ }^{1} \mathrm{H}$ NMR (300 $\left.\mathrm{MHz}, \mathrm{CD}_{3} \mathrm{CN}\right) \delta 9.44(\mathrm{~s}, 1 \mathrm{H}), 7.66(\mathrm{~s}, 1 \mathrm{H}), 7.53(\mathrm{~s}, 1 \mathrm{H}), 5.33(\mathrm{~s}$, $2 \mathrm{H}), 4.18(\mathrm{t}, J=7.0 \mathrm{~Hz}, 2 \mathrm{H}), 3.93(\mathrm{~s}, 3 \mathrm{H}), 1.62(\mathrm{tt}, J=7.5,7.5 \mathrm{~Hz}$, $2 \mathrm{H}), 1.38(\mathrm{tt}, J=7.5,7.5 \mathrm{~Hz}, 3 \mathrm{H}), 0.92(\mathrm{t}, J=7.0 \mathrm{~Hz}, 3 \mathrm{H}) .{ }^{13} \mathrm{C}(75$ MHz) $\delta 167.58,138.76,124.66,124.23,66.94,66.20,50.90,37.16$, 31.15, 19.63, 13.89. MS (ESI): $m / z, 197.2\left[\mathrm{M}-\mathrm{Br}^{-}\right]^{+}$; MS (ESI): $\mathrm{m} / \mathrm{z}, 79$ and $81\left[\mathrm{Br}^{-}\right]$.

\section{3-Methyl-1-(pentoxycarbonylmethyl)imidazolium bromide (7e)}

This compound was prepared analogously to $7 \mathbf{b}$ using 1-methylimidazole $(4.93 \mathrm{~g}, 4.78 \mathrm{~mL}, 60 \mathrm{mmol})$ in diethyl ether $(50 \mathrm{~mL})$ and pentyl bromoacetate $(15.0 \mathrm{~g}, 71.8 \mathrm{mmol})$ to give a clear viscous hygroscopic oil in $97 \%$ yield $(16.98 \mathrm{~g}, 58 \mathrm{mmol}) .{ }^{1} \mathrm{H}$ NMR $(300$ $\left.\mathrm{MHz}, \mathrm{CD}_{3} \mathrm{CN}\right) \delta 9.49(\mathrm{~s}, 1 \mathrm{H}), 7.69(\mathrm{~s}, 1 \mathrm{H}), 7.55(\mathrm{~s}, 1 \mathrm{H}), 5.36(\mathrm{~s}$, $2 \mathrm{H}), 4.16(\mathrm{t}, J=7.0 \mathrm{~Hz}, 2 \mathrm{H}), 3.94(\mathrm{~s}, 3 \mathrm{H}), 1.61(\mathrm{tt}, J=7.5,7.5 \mathrm{~Hz}$, $2 \mathrm{H}), 1.38-1.28(\mathrm{~m}, 4 \mathrm{H}), 0.89(\mathrm{t}, J=7.0 \mathrm{~Hz}, 3 \mathrm{H}) .{ }^{13} \mathrm{C}(75 \mathrm{MHz}) \delta$ 167.56, 138.75, 124.62, 124.18, 67.16, 50.87, 37.13, 28.76, 28.48, 22.84, 14.17. MS (ESI): $\mathrm{m} / \mathrm{z}, 211.1\left[\mathrm{M}-\mathrm{Br}^{-}\right]^{+} ; \mathrm{MS}$ (ESI): $\mathrm{m} / \mathrm{z}, 79$ and $81\left[\mathrm{Br}^{-}\right]$.

\section{3-Methyl-1-(hexoxycarbonylmethyl)imidazolium bromide (7f)}

To a stirred solution of 1-methylimidazole $(2.11 \mathrm{~g}, 2.05 \mathrm{~mL}, 25$ mmol $)$ in diethyl ether $(25 \mathrm{~mL})$ at $-5{ }^{\circ} \mathrm{C}$ under a nitrogen atmosphere was added dropwise hexyl bromoacetate $(6.70 \mathrm{~g}, 5.31$ $\mathrm{mL}, 30 \mathrm{mmol}$ ). The reaction mixture was stirred vigorously at -5 ${ }^{\circ} \mathrm{C}$ for $1 \mathrm{~h}$, then at $\mathrm{rt}$ for $3 \mathrm{~h}$. The diethyl ether top phase was decanted and the IL washed with diethyl ether $(3 \times 10 \mathrm{~mL})$ then residual solvent removed in vacuo. The product was dried at $60^{\circ} \mathrm{C}$ at $0.01 \mathrm{mmHg}$ for $72 \mathrm{~h}$ to give a clear viscous hygroscopic oil in $92 \%$ yield $(7.01 \mathrm{~g}, 23.0 \mathrm{mmol}) .{ }^{1} \mathrm{H} \mathrm{NMR}\left(300 \mathrm{MHz}, \mathrm{CD}_{3} \mathrm{CN}\right) \delta$ $9.49(\mathrm{~s}, 1 \mathrm{H}), 7.69(\mathrm{~s}, 1 \mathrm{H}), 7.56(\mathrm{~s}, 1 \mathrm{H}), 5.36(\mathrm{~s}, 2 \mathrm{H}), 4.15(\mathrm{t}, J=7.0$ $\mathrm{Hz}, 2 \mathrm{H}), 3.93$ (s, 3H), 1.67-1.57 (m, 2H), 1.40-1.25 (m, 6H), 0.87 $(\mathrm{t}, J=7.0 \mathrm{~Hz}, 3 \mathrm{H}) .{ }^{13} \mathrm{C}(75 \mathrm{MHz}) \delta 167.95,139.03,124.95$, 124.54, 67.51, 51.20, 37.50, 32.32, 29.36, 26.35, 23.48, 14.60. MS (ESI): $m / z, 225.2\left[\mathrm{M}-\mathrm{Br}^{-}\right]^{+}$; MS (ESI): $m / z, 79$ and $81\left[\mathrm{Br}^{-}\right]$.

\section{3-Methyl-1-(octoxycarbonylmethyl)imidazolium bromide (7g)}

This compound was prepared analogously to 7f using 1-methylimidazole $(0.84 \mathrm{~g}, 0.82 \mathrm{~mL}, 10.3 \mathrm{mmol})$ and octyl bromoacetate $(3.01 \mathrm{~g}, 12.0 \mathrm{mmol})$ to give a clear viscous hygroscopic oil in $95 \%$ yield (3.26 g, $9.8 \mathrm{mmol}) .{ }^{1} \mathrm{H} \mathrm{NMR}\left(300 \mathrm{MHz}, \mathrm{CD}_{3} \mathrm{CN}\right) \delta 9.41(\mathrm{~s}$, $1 \mathrm{H}), 7.64(\mathrm{~s}, 1 \mathrm{H}), 7.53(\mathrm{~s}, 1 \mathrm{H}), 5.32(\mathrm{~s}, 2 \mathrm{H}), 4.17(\mathrm{t}, J=7.0 \mathrm{~Hz}$, 2H). $3.94(\mathrm{~s}, 3 \mathrm{H}), 1.70-1.60(\mathrm{~m}, 2 \mathrm{H}), 1.40-1.20(\mathrm{~m}, 10 \mathrm{H}), 0.88(\mathrm{t}$, $J=7.0 \mathrm{~Hz}, 3 \mathrm{H}) .{ }^{13} \mathrm{C}(75 \mathrm{MHz}) \delta 167.97,139.08,125.00,124.59$, 67.58, 51.23, 37.52, 32.84, 30.23, 30.18, 29.48, 26.75, 23.68, 14.73 . MS (ESI): $\mathrm{m} / \mathrm{z}, 253.3\left[\mathrm{M}-\mathrm{Br}^{-}\right]^{+}$; MS (ESI): $\mathrm{m} / \mathrm{z}, 79$ and 81 $\left[\mathrm{Br}^{-}\right]$.

\section{3-Methyl-1-(N-butylcarbamoylmethyl)imidazolium bromide (7h)}

This compound was prepared analogously to $7 \mathbf{f}$ using 1-methylimidazole $(0.42 \mathrm{~g}, 0.41 \mathrm{~mL}, 5.0 \mathrm{mmol})$ and $N$-butyl-2-bromoacetamide $(1.16 \mathrm{~g}, 6.0 \mathrm{mmol})$ to give an oil in $94 \%$ yield $(1.30 \mathrm{~g}, 4.7 \mathrm{mmol})$. The oil slowly crystallised at room temperature. ${ }^{1} \mathrm{H}$ NMR (300 $\left.\mathrm{MHz}, \mathrm{CD}_{3} \mathrm{CN}\right) \delta 9.11(\mathrm{~s}, 1 \mathrm{H}), 8.39$ (bs, $\left.1 \mathrm{H}, \mathrm{NH}\right), 7.56(\mathrm{~s}, 1 \mathrm{H}), 7.45$ $(\mathrm{s}, 1 \mathrm{H}), 5.14(\mathrm{~s}, 2 \mathrm{H}), 3.90(\mathrm{~s}, 3 \mathrm{H}), 3.15(\mathrm{q}, J=7.0 \mathrm{~Hz}, 2 \mathrm{H})$, $1.52-1.40(\mathrm{~m}, 2 \mathrm{H}), 1.40-1.37(\mathrm{~m}, 2 \mathrm{H}), 0.87(\mathrm{t}, J=7.0 \mathrm{~Hz}, 3 \mathrm{H}) .{ }^{13} \mathrm{C}$ NMR (75 MHz) $\delta 166.12,138.89,124.99,124.58,52.70,40.48$, 37.62, 32.55, 21.28, 14.57. MS (ESI): $\mathrm{m} / \mathrm{z}, 196.1\left[\mathrm{M}-\mathrm{Br}^{-}\right]^{+}$; MS (ESI): $m / z, 79$ and $81\left[\mathrm{Br}^{-}\right]$.

\section{3-Methyl-1-( $N$-butyl- $N$-methylcarbamoylmethyl)- imidazolium bromide (7i)}

To a stirred solution of 1-methylimidazole $(821 \mathrm{mg}, 0.80 \mathrm{~mL}, 10$ $\mathrm{mmol})$ in THF $(15 \mathrm{~mL})$ at $-5^{\circ} \mathrm{C}$ under a nitrogen atmosphere was added dropwise $N$-butyl- $N$-methyl-2-bromoacetamide $(2.50 \mathrm{~g}, 12$ mmol, $1: 1.3$ mixture of isomers $)$ in THF $(5 \mathrm{~mL})$. The reaction mixture was stirred vigorously at $-5{ }^{\circ} \mathrm{C}$ for $1 \mathrm{~h}$, then at $\mathrm{rt}$ for $48 \mathrm{~h}$. The THF top phase was decanted and the IL washed with THF (2 $\times 5 \mathrm{~mL}$ ), then residual solvent removed in vacuo. The product was dried at $60{ }^{\circ} \mathrm{C}$ at $0.01 \mathrm{mmHg}$ for $72 \mathrm{~h}$ to give a clear viscous hygroscopic oil in $95 \%$ yield $(2.76 \mathrm{~g}, 9.51 \mathrm{mmol})$ * denotes both isomers. ${ }^{1} \mathrm{H}$ NMR $\left(300 \mathrm{MHz}, \mathrm{CD}_{3} \mathrm{CN}\right) \delta 8.78$ (s, $1 \mathrm{H}$, minor), 8.74 (s, 1H, major), 7.43-7.35 (m, 2H*), 5.22 (s, 2H, major), 5.19 (s, 2H, minor), 3.90 (s, $\left.3 \mathrm{H}^{*}\right), 3.37(\mathrm{t}, J=7.0 \mathrm{~Hz}, 2 \mathrm{H}$, major), $3.30(\mathrm{t}, J=$ $7.0 \mathrm{~Hz}, 2 \mathrm{H}$, minor), 3.02 (s, 3H, major), 2.92 (s, 3H, minor), $1.70-1.25\left(\mathrm{~m}, 4 \mathrm{H}^{*}\right), 0.99(\mathrm{t}, J=7.0 \mathrm{~Hz}, 3 \mathrm{H}$, minor), $0.93(\mathrm{t}, J=$ $7.0 \mathrm{~Hz}, 3 \mathrm{H}$, major). ${ }^{13} \mathrm{C}(75 \mathrm{MHz}) \delta 165.85$ (major), 165.53 (minor), 138.89 (minor), 138.72 (major), 125.01 (minor), 124.91 (major), 123.75 (minor), 123.72 (major), 51.70 (major), 51.33 (minor), 49.64 (minor), 48.53 (major), 37.19*, 34.96 (major), 34.24 (minor), 30.86 (minor), 29.94 (major), 20.69 (minor), 20.58 (major), 14.25*. MS (ESI): $\mathrm{m} / z, 210.2\left[\mathrm{M}-\mathrm{Br}^{-}\right]^{+}$; MS (ESI): $\mathrm{m} / z$, 79 and $81\left[\mathrm{Br}^{-}\right]$.

\section{3-Methyl-1-( $N, N$-diethylcarbamoylmethyl)imidazolium bromide $(7 \mathbf{j})$}

This compound was prepared analogously to $7 \mathbf{b}$ using 1-methylimidazole ( $1.05 \mathrm{~g}, 1.02 \mathrm{~mL}, 12.8 \mathrm{mmol})$ and $N, N$-diethyl-2-bromoacetamide $(2.98 \mathrm{~g}, 15.4 \mathrm{mmol})$ to give a crystalline solid in $99 \%$ yield (3.51 g, $12.7 \mathrm{mmol}) . \mathrm{mp}=66-68{ }^{\circ} \mathrm{C} ;{ }^{1} \mathrm{H} \mathrm{NMR}(300 \mathrm{MHz}$, $\left.\mathrm{CD}_{3} \mathrm{CN}\right) \delta 9.27(\mathrm{~s}, 1 \mathrm{H}), 7.60(\mathrm{~s}, 1 \mathrm{H}), 7.47(\mathrm{~s}, 1 \mathrm{H}), 5.44(\mathrm{~s}, 2 \mathrm{H}), 3.91$ $(\mathrm{s}, 3 \mathrm{H}), 3.37(\mathrm{q}, J=7.0 \mathrm{~Hz}, 2 \mathrm{H}), 3.34(\mathrm{q}, J=7.0 \mathrm{~Hz}, 2 \mathrm{H}), 1.24(\mathrm{t}$, $J=7.0 \mathrm{~Hz}, 3 \mathrm{H}), 1.06(\mathrm{t}, J=7.0 \mathrm{~Hz}, 3 \mathrm{H}) .{ }^{13} \mathrm{C}(75 \mathrm{MHz}) \delta 165.17$, 139.25, 125.54, 124.14, 51.80, 42.60, 41.97, 37.55, 14.86, 13.67 . MS (ESI): $m / z, 196.1\left[\mathrm{M}-\mathrm{Br}^{-}\right]^{+}$; MS (ESI): $m / z, 79$ and 81 $\left[\mathrm{Br}^{-}\right]$. 


\section{3-Methyl-1-(methoxycarbonylmethyl)imidazolium $\mathrm{BF}_{4}$ (8a)}

A dry flask was charged with 3-methyl-1-(methoxycarbonylmethy1)imidazolium bromide (7a) $(702 \mathrm{mg}, 3.0 \mathrm{mmol})$ and acetonitrile (2 $\mathrm{mL}$ ) under a nitrogen atmosphere. $\mathrm{NaBF}_{4}(362 \mathrm{mg}, 3.3 \mathrm{mmol})$ was added in one portion and the suspension was stirred vigorously for 4 days at rt. The fine white precipitate was filtered quickly in air and washed with dry acetonitrile $(2 \times 1 \mathrm{~mL})$. The filtrate and washings were combined, solvent removed by rotary evaporation then in vacuo. The product was dried at $60{ }^{\circ} \mathrm{C}$ at $0.01 \mathrm{mmHg}$ for $72 \mathrm{~h}$ to give a clear viscous hygroscopic oil in $96 \%$ yield $(0.70 \mathrm{~g}, 2.9$ mmol). ${ }^{1} \mathrm{H}$ NMR $\left(300 \mathrm{MHz}, \mathrm{CD}_{3} \mathrm{CN}\right) \delta 8.58(\mathrm{~s}, 1 \mathrm{H}), 7.40(\mathrm{~s}, 2 \mathrm{H})$, $5.02(\mathrm{~s}, 2 \mathrm{H}), 3.89(\mathrm{~s}, 3 \mathrm{H}), 3.78(\mathrm{~s}, 3 \mathrm{H}) .{ }^{13} \mathrm{C}(75 \mathrm{MHz}) \delta 168.33$, $138.75,125.15,125.00,54.33,51.18,37.63 .{ }^{19} \mathrm{~F}(254 \mathrm{MHz}) \delta$ $-151.6\left(\mathrm{BF}_{4}^{-}\right)$. MS (ESI): $m / z, 155.1\left[\mathrm{M}-\mathrm{BF}_{4}^{-}\right]^{+} ; \mathrm{MS}(\mathrm{ESI}): \mathrm{m} / \mathrm{z}$, $87.0\left[\mathrm{BF}_{4}^{-}\right]$.

\section{3-Methyl-1-(ethoxycarbonylmethyl)imidazolium $\mathrm{BF}_{\mathbf{4}}(\mathbf{8 b})$}

This compound was prepared analogously to 8a using 3-methyl1-(ethoxycarbonylmethyl)imidazolium bromide $7 \mathbf{b}$ (1.79 g, 6.3 mmol $)$ and $\mathrm{NaBF}_{4}(0.69 \mathrm{~g}, 6.3 \mathrm{mmol})$ to give a clear viscous hygroscopic oil in $92 \%$ yield $(1.51 \mathrm{~g}, 5.9 \mathrm{mmol}) .{ }^{1} \mathrm{H}$ NMR (300 $\left.\mathrm{MHz}, \mathrm{CD}_{3} \mathrm{CN}\right) \delta 8.66(\mathrm{~s}, 1 \mathrm{H}), 7.44(\mathrm{~s}, 1 \mathrm{H}), 7.40(\mathrm{~s}, 1 \mathrm{H}), 5.30(\mathrm{~s}$ $2 \mathrm{H}), 4.25(\mathrm{q}, J=7.0 \mathrm{~Hz}, 2 \mathrm{H}), 3.89(\mathrm{~s}, 3 \mathrm{H}), 1.29(\mathrm{t}, J=7.0 \mathrm{~Hz}, 3 \mathrm{H})$. ${ }^{13} \mathrm{C}(75 \mathrm{MHz}) \delta 167.83,138.80,125.16,124.93,63.90,51.31$, 37.64, 14.83. ${ }^{19} \mathrm{~F}(254 \mathrm{MHz}) \delta-151.6\left(\mathrm{BF}_{4}^{-}\right)$. MS (ESI): $\mathrm{m} / z$, $169.1\left[\mathrm{M}-\mathrm{BF}_{4}^{-}\right]^{+} ; \mathrm{MS}(\mathrm{ESI}): \mathrm{m} / z, 87.0\left[\mathrm{BF}_{4}^{-}\right]$.

\section{3-Methyl-1-(propoxycarbonylmethyl)imidazolium $\mathrm{BF}_{4}(8 \mathrm{c})$}

This compound was prepared analogously to 8a using 3-methyl1-(propoxycarbonylmethyl)imidazolium bromide 7c (722 mg, 2.8 mmol) and $\mathrm{NaBF}_{4}(333 \mathrm{mg}, 3.0 \mathrm{mmol})$ to give a clear viscous hygroscopic oil in $98 \%$ yield $(727 \mathrm{mg}, 2.7 \mathrm{mmol}) .{ }^{1} \mathrm{H}$ NMR (300 $\left.\mathrm{MHz}, \mathrm{CD}_{3} \mathrm{CN}\right) \delta 8.55(\mathrm{~s}, 1 \mathrm{H}), 7.41(\mathrm{~s}, 2 \mathrm{H}), 7.40(\mathrm{~s}, 1 \mathrm{H}), 5.00(\mathrm{~s}$, $2 \mathrm{H}), 4.17(\mathrm{t}, J=7.0 \mathrm{~Hz}, 2 \mathrm{H}), 3.88$ (s, 3H), 1.70 (qt, $J=7.0,7.0$ $\mathrm{Hz}, 2 \mathrm{H}), 0.95(\mathrm{t}, J=7.0 \mathrm{~Hz}, 3 \mathrm{H}) .{ }^{13} \mathrm{C}(75 \mathrm{MHz}) \delta 167.90,138.76$, $125.15,124.9,69.24,51.22,37.58,23.00,10.96 .{ }^{19} \mathrm{~F}(254 \mathrm{MHz}) \delta$ $-151.5\left(\mathrm{BF}_{4}^{-}\right)$. MS (ESI): $\mathrm{m} / \mathrm{z}, 183.1\left[\mathrm{M}-\mathrm{BF}_{4}^{-}\right]^{+}$; MS (ESI): $\mathrm{m} / \mathrm{z}$, $87.0\left[\mathrm{BF}_{4}^{-}\right]$.

\section{3-Methyl-1-(hexoxycarbonylmethyl)imidazolium $\mathrm{BF}_{4}(\mathbf{8 f})$}

This compound was prepared analogously to 8a using 3-methyl1-(hexoxycarbonylmethyl)imidazolium bromide $7 \mathbf{f}(758 \mathrm{mg}, 2.25$ mmol) and $\mathrm{NaBF}_{4}(247 \mathrm{mg}, 2.50 \mathrm{mmol})$ to give a clear viscous hygroscopic oil in $90 \%$ yield $(630 \mathrm{mg}, 2.0 \mathrm{mmol}) .{ }^{1} \mathrm{H}$ NMR (300 $\left.\mathrm{MHz}, \mathrm{CD}_{3} \mathrm{CN}\right) \delta 8.63(\mathrm{~s}, 1 \mathrm{H}), 7.43(\mathrm{~s}, 2 \mathrm{H}), 7.40(\mathrm{~s}, 1 \mathrm{H}), 5.02(\mathrm{~s}$, $2 \mathrm{H}), 4.19(\mathrm{t}, J=7.0 \mathrm{~Hz}, 2 \mathrm{H}), 3.88(\mathrm{~s}, 3 \mathrm{H}), 1.70-1.60(\mathrm{~m}, 2 \mathrm{H})$, $1.42-1.28(\mathrm{~m}, 6 \mathrm{H}), 0.91(\mathrm{t}, J=7.0 \mathrm{~Hz}, 3 \mathrm{H}) .{ }^{13} \mathrm{C}(75 \mathrm{MHz}) \delta$ $167.85,138.76,125.17,124.94,67.87,51.30,37.64,32.55,29.56$, $26.58,23.72,14.77 .{ }^{19} \mathrm{~F}(254 \mathrm{MHz}) \delta-151\left(\mathrm{BF}_{4}{ }^{-}\right)$. MS (ESI): $\mathrm{m} / z$ $225.2\left[\mathrm{M}-\mathrm{BF}_{4}^{-}\right]^{+} \mathrm{MS}(\mathrm{ESI}): \mathrm{m} / \mathrm{z}, 87.0\left[\mathrm{BF}_{4}{ }^{-}\right]$.

\section{3-Methyl-1-(octoxycarbonylmethyl)imidazolium $\mathrm{BF}_{4}(8 \mathrm{~g})$}

This compound was prepared analogously to 8a using 3-methyl1-(octoxycarbonylmethyl)imidazolium bromide $7 \mathbf{g}(350 \mathrm{mg}, 1.05$ mmol) and $\mathrm{NaBF}_{4}(127 \mathrm{mg}, 1.16 \mathrm{mmol})$ to give a clear viscous hygroscopic oil in $97 \%$ yield $(346 \mathrm{mg}, 1.02 \mathrm{mmol})$. The oil crystallised in the freezer at $-18{ }^{\circ} \mathrm{C} .{ }^{1} \mathrm{H}$ NMR $\left(300 \mathrm{MHz}, \mathrm{CD}_{3} \mathrm{CN}\right)$ $\delta 8.50(\mathrm{~s}, 1 \mathrm{H}), 7.40(\mathrm{~s}, 2 \mathrm{H}), 7.38(\mathrm{~s}, 1 \mathrm{H}), 4.98(\mathrm{~s}, 2 \mathrm{H}), 4.19(\mathrm{t}, J=$ $7.0 \mathrm{~Hz}, 2 \mathrm{H}), 3.88(\mathrm{~s}, 3 \mathrm{H}), 1.70-1.60(\mathrm{~m}, 2 \mathrm{H}), 1.42-1.25(\mathrm{~m}, 10 \mathrm{H})$ $0.91(\mathrm{t}, J=7.0 \mathrm{~Hz}, 3 \mathrm{H}) .{ }^{13} \mathrm{C}(75 \mathrm{MHz}) \delta 167.87,138.79,125.16$, $124.95,67.85,51.25,37.60,33.00,30.38,30.32$, 29.59, 26.89, 23.83, 14.88. ${ }^{19} \mathrm{~F}(254 \mathrm{MHz}) \delta-151.4\left(\mathrm{BF}_{4}^{-}\right)$. MS (ESI): $\mathrm{m} / z$, $253.3\left[\mathrm{M}-\mathrm{BF}_{4}^{-}\right]^{+} ; \mathrm{MS}(\mathrm{ESI}): \mathrm{m} / z, 87.0\left[\mathrm{BF}_{4}^{-}\right]$.
3-Methyl-1-( $N$-butylcarbamoylmethyl)imidazolium $\mathrm{BF}_{4}$ (8h)

This compound was prepared analogously to 8a using 3-methyl1-(N-butylcarbamoylmethyl)imidazolium bromide $7 \mathbf{h}(128 \mathrm{mg}$, $0.45 \mathrm{mmol})$ and $\mathrm{NaBF}_{4}(50 \mathrm{mg}, 0.50 \mathrm{mmol})$ in acetonitrile $(1 \mathrm{~mL})$ to give a clear viscous hygroscopic oil in $86 \%$ yield $(110 \mathrm{mg}, 0.39$ mmol). ${ }^{1} \mathrm{H}$ NMR $\left(300 \mathrm{MHz}, \mathrm{CD}_{3} \mathrm{CN}\right) \delta 8.55(\mathrm{~s}, 1 \mathrm{H}), 7.39(\mathrm{~s}, 1 \mathrm{H})$, 7.35 (s, 1H), 7.05 (bs, 1H, NH), $4.85(\mathrm{~s}, 2 \mathrm{H}), 3.86(\mathrm{~s}, 3 \mathrm{H}), 3.20$ (q, $J=7.0 \mathrm{~Hz}, 2 \mathrm{H}), 1.55-1.40(\mathrm{tt}, J=7.0,7.0 \mathrm{~Hz}, 2 \mathrm{H}), 1.40-1.28$ (qt, $J=7.0,7.0 \mathrm{~Hz}, 2 \mathrm{H}), 0.92(\mathrm{t}, J=7.0 \mathrm{~Hz}, 3 \mathrm{H}) .{ }^{13} \mathrm{C}(75 \mathrm{MHz}) \delta$ $165.73,138.65,125.10,124.59,52.39,20.54,37.50,32.52,21.11$, 14.45. ${ }^{19} \mathrm{~F}(254 \mathrm{MHz}) \delta-151.7\left(\mathrm{BF}_{4}^{-}\right)$. MS (ESI): $\mathrm{m} / \mathrm{z}, 196.1$ $\left[\mathrm{M}-\mathrm{BF}_{4}^{-}\right]^{+} ; \mathrm{MS}(\mathrm{ESI}): \mathrm{m} / z, 87.0\left[\mathrm{BF}_{4}^{-}\right]$.

\section{3-Methyl-1-( $N$-butyl- $N$-methylcarbamoylmethyl)- imidazolium $\mathrm{BF}_{4}(8 \mathrm{i})$}

This compound was prepared analogously to 8a using 3-methyl1-( $N$-butyl- $N$-methylcarbamoylmethyl)imidazolium bromide $7 \mathbf{i}$ (256 mg, $0.88 \mathrm{mmol}, 1: 1.3$ mixture of isomers) and $\mathrm{NaBF}_{4}$ (107 $\mathrm{mg}, 0.97 \mathrm{mmol}$ ) to give a clear viscous hygroscopic oil in $98 \%$ yield (256 mg, $0.86 \mathrm{mmol}, 1: 1.3$ mixture of isomers). * denotes both isomers. ${ }^{1} \mathrm{H}$ NMR $\left(300 \mathrm{MHz}, \mathrm{CD}_{3} \mathrm{CN}\right) \delta 8.46$ (s, $1 \mathrm{H}$, minor), 8.44 (s, $1 \mathrm{H}$, major), $7.40-7.30\left(\mathrm{~m}, 2 \mathrm{H}^{*}\right), 5.08$ (s, $2 \mathrm{H}$, minor), $5.05(\mathrm{~s}, 2 \mathrm{H}$ major), $3.88\left(\mathrm{~s}, 3 \mathrm{H}^{*}\right), 3.37(\mathrm{t}, J=7.0 \mathrm{~Hz}, 2 \mathrm{H}$, major), $3.28(\mathrm{t}, J=$ $7.0 \mathrm{~Hz}, 2 \mathrm{H}$, minor), 3.00 (s, 3H, major), 2.92 (s, 3H, minor), $1.70-1.25\left(\mathrm{~m}, 4 \mathrm{H}^{*}\right), 0.99(\mathrm{t}, J=7.0 \mathrm{~Hz}, 3 \mathrm{H}$, minor), $0.93(\mathrm{t}, J=$ $7.0 \mathrm{~Hz}, 3 \mathrm{H}$, major). ${ }^{13} \mathrm{C}(75 \mathrm{MHz}) \delta 166.05$ (major), 165.79 (minor), 139.14 (minor), 139.04 (major), 125.48 (minor), 125.44 (major), 124.43*, 121.42* (q, $J=320 \mathrm{~Hz}, \mathrm{CF}_{3}$ ), 51.76 (major), 51.51 (minor), 50.01 (minor), 49.15 (major), 37.41*, 35.07 (major), 34.65 (minor), 31.21 (minor), 30.35 (major), 21.10 (minor), 21.09 (major), 14.74 (major), 14.69 (minor). ${ }^{19} \mathrm{~F}$ (254 MHz) $\delta-152.10$ $\left(\mathrm{BF}_{4}^{-}\right)$. MS (ESI): $\mathrm{m} / \mathrm{z}, 210.2\left[\mathrm{M}-\mathrm{BF}_{4}^{-}\right]^{+}$; MS (ESI): $\mathrm{m} / \mathrm{z}, 87.0$ $\left[\mathrm{BF}_{4}^{-}\right]$.

\section{3-Methyl-1-( $N, N$-diethylcarbamoylmethyl)- imidazolium $\mathrm{BF}_{4}(8 \mathbf{j})$}

This compound was prepared analogously to 8a using 3-methyl1-(N,N-diethylcarbamoylmethyl)imidazolium bromide $7 \mathbf{j}$ (552 $\mathrm{mg}$, $2.0 \mathrm{mmol})$ and $\mathrm{NaBF}_{4}(242 \mathrm{mg}, 2.2 \mathrm{mmol})$ to give a clear viscous hygroscopic oil in $92 \%$ yield $(520 \mathrm{mg}, 1.84 \mathrm{mmol}) .{ }^{1} \mathrm{H}$ NMR (300 $\left.\mathrm{MHz}, \mathrm{CD}_{3} \mathrm{CN}\right) \delta 8.55(\mathrm{~s}, 1 \mathrm{H}), 7.38(\mathrm{~s}, 2 \mathrm{H}), 5.10(\mathrm{~s}, 2 \mathrm{H}), 3.83(\mathrm{~s}$, $3 \mathrm{H}), 3.30(\mathrm{~m}, 4 \mathrm{H}), 1.19(\mathrm{t}, J=7.0 \mathrm{~Hz}), 1.07(\mathrm{t}, J=7.0 \mathrm{~Hz}) .{ }^{13} \mathrm{C}(75$ MHz) $\delta 163.72,137.68,124.10,122.95,50.22,41.12,40.58$, $36.01,13.25,12.21 .{ }^{19} \mathrm{~F}(254 \mathrm{MHz}) \delta-150.8\left(\mathrm{BF}_{4}{ }^{-}\right)$. MS (ESI): $m /$ $z, 196.1\left[\mathrm{M}-\mathrm{BF}_{4}^{-}\right]^{+}$; MS (ESI): $m / z, 87.0\left[\mathrm{BF}_{4}^{-}\right]$.

\section{3-Methyl-1-(methoxycarbonylmethyl)imidazolium $\mathbf{P F}_{6}$} (9a)

A flask was charged with 3-methyl-1-(methoxycarbonylmethyl)imidazolium bromide $7 \mathbf{a}(702 \mathrm{mg}, 3.0 \mathrm{mmol})$ and distilled water (2 $\mathrm{mL}) . \mathrm{KPF}_{6}(607 \mathrm{mg}, 3.3 \mathrm{mmol})$ in distilled water $(1 \mathrm{~mL})$ was added in one portion and the suspension was stirred vigorously for $4 \mathrm{~h}$ at rt. The top aqueous layer was removed, the IL washed with water $(3 \times 1 \mathrm{~mL})$ then the solvent removed in vacuo. The product was dried at $60{ }^{\circ} \mathrm{C}$ at $0.01 \mathrm{mmHg}$ for $72 \mathrm{~h}$ to give a crystalline solid in $67 \%$ yield $(0.61 \mathrm{~g}, 2.0 \mathrm{mmol}) . \mathrm{mp}=76-78{ }^{\circ} \mathrm{C} ;{ }^{1} \mathrm{H}$ NMR $(300$ $\left.\mathrm{MHz}, \mathrm{CD}_{3} \mathrm{CN}\right) \delta 8.49(\mathrm{~s}, 1 \mathrm{H}), 7.39(\mathrm{~s}, 2 \mathrm{H}), 4.99(\mathrm{~s}, 2 \mathrm{H}), 3.88(\mathrm{~s}$, $3 \mathrm{H}), 3.79(\mathrm{~s}, 3 \mathrm{H}) .{ }^{13} \mathrm{C}(75 \mathrm{MHz}) \delta 168.32,138.67,125.14,125.02$, $54.35,51.18,37.64 ;{ }^{19} \mathrm{~F}(254 \mathrm{MHz}) \delta-73.0\left(\mathrm{~d}, J_{\mathrm{P}-\mathrm{F}}=707 \mathrm{~Hz}\right.$, $\mathrm{PF}_{6}{ }^{-}$); MS (ESI): $\mathrm{m} / z, 155.1\left[\mathrm{M}-\mathrm{PF}_{6}^{-}\right]^{+} ; \mathrm{MS}$ (ESI): $\mathrm{m} / \mathrm{z}, 144.9$ $\left[\mathrm{PF}_{6}^{-}\right]$.

\section{3-Methyl-1-(ethoxycarbonylmethyl)imidazolium $\mathrm{PF}_{6}(9 \mathrm{~b})$}

This compound was prepared analogously to 9a using 3-methyl1-(ethoxycarbonylmethyl)imidazolium bromide $7 \mathbf{b}(0.55 \mathrm{~g}, 2.2$ $\mathrm{mmol})$ and $\mathrm{KPF}_{6}(0.41 \mathrm{~g}, 2.2 \mathrm{mmol})$ to give a clear viscous oil in 
$68 \%$ yield $(0.47 \mathrm{~g}, 1.5 \mathrm{mmol}) .{ }^{1} \mathrm{H}$ NMR $\left(300 \mathrm{MHz}, \mathrm{CD}_{3} \mathrm{CN}\right) \delta 8.47$ (s, 1H), 7.39 (s, 2H), $4.97(\mathrm{~s}, 2 \mathrm{H}), 4.26(\mathrm{q}, J=7.0 \mathrm{~Hz}, 2 \mathrm{H}), 3.88$ $(\mathrm{s}, 3 \mathrm{H}), 1.29(\mathrm{t}, J=7.0 \mathrm{~Hz}, 3 \mathrm{H}) .{ }^{13} \mathrm{C}(75 \mathrm{MHz}) \delta 167.80,138.65$, $125.18,125.00,63.98,51.30,37.63,14.84 .{ }^{19} \mathrm{~F}(254 \mathrm{MHz}) \delta-72.5$ $\left(\mathrm{d}, J_{\mathrm{P}-\mathrm{F}}=707 \mathrm{~Hz}, \mathrm{PF}_{6}{ }^{-}\right) . \mathrm{MS}(\mathrm{ESI}): m / z, 169.1\left[\mathrm{M}-\mathrm{PF}_{6}{ }^{-}\right]^{+} ; \mathrm{MS}$ (ESI): $m / z, 144.9\left[\mathrm{PF}_{6}{ }^{-}\right]$.

\section{3-Methyl-1-(propoxycarbonylmethyl)imidazolium $\mathrm{PF}_{6}$ (9c)}

This compound was prepared analogously to 9a using 3-methyl1-(propoxycarbonylmethyl)imidazolium bromide 7c $(0.60 \mathrm{~g}, 2.3$ $\mathrm{mmol})$ and $\mathrm{KPF}_{6}(464 \mathrm{mg}, 2.5 \mathrm{mmol})$ to give a clear viscous oil in $78 \%$ yield $(585 \mathrm{mg}, 1.8 \mathrm{mmol}) .{ }^{1} \mathrm{H}$ NMR $\left(300 \mathrm{MHz}, \mathrm{CD}_{3} \mathrm{CN}\right) \delta$ $8.47(\mathrm{~s}, 1 \mathrm{H}), 7.39(\mathrm{~s}, 2 \mathrm{H}), 4.98(\mathrm{~s}, 2 \mathrm{H}), 4.17(\mathrm{t}, J=7.0 \mathrm{~Hz}, 2 \mathrm{H})$, $3.88(\mathrm{~s}, 3 \mathrm{H}), 1.69$ (qt, $J=7.0,7.0 \mathrm{~Hz}, 2 \mathrm{H}), 0.95(\mathrm{t}, J=7.0 \mathrm{~Hz}, 3 \mathrm{H})$; ${ }^{13} \mathrm{C}(75 \mathrm{MHz}) \delta 167.84,138.65,125.18,124.99,69.32,51.28$, $37.64,23.03,10.98 ;{ }^{19} \mathrm{~F}(254 \mathrm{MHz}) \delta-72.7\left(\mathrm{~d}, J_{\mathrm{P}-\mathrm{F}}=707 \mathrm{~Hz}\right.$, $\mathrm{PF}_{6}{ }^{-}$); MS (ESI): $\mathrm{m} / z, 183.1\left[\mathrm{M}-\mathrm{PF}_{6}{ }^{-}\right]+$; MS (ESI): $\mathrm{m} / z, 144.9$ $\left[\mathrm{PF}_{6}{ }^{-}\right]$.

\section{3-Methyl-1-(hexoxycarbonylmethyl)imidazolium $\mathbf{P F}_{6}$ (9d)}

This compound was prepared analogously to 9a using 3-methyl1-(hexoxycarbonylmethyl)imidazolium bromide 7d (762 mg, 2.3 mmol) and $\mathrm{KPF}_{6}(458 \mathrm{mg}, 2.5 \mathrm{mmol})$ to give a clear viscous oil in $89 \%$ yield $(0.76 \mathrm{~g}, 2.1 \mathrm{mmol}) .{ }^{1} \mathrm{H}$ NMR $\left(300 \mathrm{MHz}, \mathrm{CD}_{3} \mathrm{CN}\right) \delta 8.49$ (s, 1H), $7.39(\mathrm{~s}, 2 \mathrm{H}), 4.98(\mathrm{~s}, 2 \mathrm{H}), 4.20(\mathrm{t}, J=7.0 \mathrm{~Hz}, 2 \mathrm{H}), 3.88(\mathrm{~s}$, $3 \mathrm{H}), 1.70-1.60(\mathrm{~m}, 2 \mathrm{H}), 1.40-1.30(\mathrm{~m}, 6 \mathrm{H}), 0.90(\mathrm{t}, J=7.0 \mathrm{~Hz}$, $3 \mathrm{H}) .{ }^{13} \mathrm{C}(75 \mathrm{MHz}) \delta 167.78,138.62,125.17,124.97,67.89,51.28$, $37.62,32.54,29.56,26.57,23.71,14.77 .{ }^{19} \mathrm{~F}(254 \mathrm{MHz}) \delta-71.94$ $\left(\mathrm{d}, J_{\mathrm{P}-\mathrm{F}}=707 \mathrm{~Hz}, \mathrm{PF}_{6}^{-}\right.$). MS (ESI): $m / z, 225.2\left[\mathrm{M}-\mathrm{PF}_{6}^{-}\right]^{+} \mathrm{MS}$ (ESI): $m / z, 144.9\left[\mathrm{PF}_{6}{ }^{-}\right.$.

\section{3-Methyl-1-(octoxycarbonylmethyl)imidazolium $\mathbf{P F}_{6}$ (9g)}

This compound was prepared analogously to 9a using 3-methyl1-(octoxycarbonylmethyl)imidazolium bromide $7 \mathrm{~g}(528 \mathrm{mg}, 1.58$ mmol) and $\mathrm{KPF}_{6}(321 \mathrm{mg}, 1.74 \mathrm{mmol})$ to give a colourless oil in $81 \%$ yield (508 mg, $1.27 \mathrm{mmol}$ ). The oil crystallised in the fridge at $2{ }^{\circ} \mathrm{C} .{ }^{1} \mathrm{H}$ NMR $\left(300 \mathrm{MHz}, \mathrm{CD}_{3} \mathrm{CN}\right) \delta 8.46(\mathrm{~s}, 1 \mathrm{H}), 7.39(\mathrm{~s}, 2 \mathrm{H})$, $4.96(\mathrm{~s}, 2 \mathrm{H}), 4.19(\mathrm{t}, J=7.0 \mathrm{~Hz}, 2 \mathrm{H}), 3.88(\mathrm{~s}, 3 \mathrm{H}), 1.72-1.60(\mathrm{~m}$, $2 \mathrm{H}), 1.42-1.25(\mathrm{~m}, 10 \mathrm{H}), 0.90(\mathrm{t}, J=7.0 \mathrm{~Hz}, 3 \mathrm{H}) .{ }^{13} \mathrm{C}(75 \mathrm{MHz})$ $\delta 167.77,138.57,125.15,124.96,67.88,51.26,37.62,32.99,30.38$, $30.31,29.58,26.89,23.84,14.86 .{ }^{19} \mathrm{~F}(254 \mathrm{MHz}) \delta-72.67\left(\mathrm{~d}, J_{\mathrm{P}-\mathrm{F}}\right.$ $\left.=707 \mathrm{~Hz}, \mathrm{PF}_{6}{ }^{-}\right) ; \mathrm{MS}(\mathrm{ESI}): \mathrm{m} / z, 253.3\left[\mathrm{M}-\mathrm{PF}_{6}{ }^{-}\right]+$MS (ESI): $m /$ $z, 144.9\left[\mathrm{PF}_{6}{ }^{-}\right]$.

\section{3-Methyl-1-( $N$-butylcarbamoylmethyl)imidazolium PF $_{6}$ (9h)}

A dry flask was charged with 3-methyl-1-( $N$-butylcarbamoylmethyl)imidazolium bromide $7 \mathbf{h}(120 \mathrm{mg}, 0.43 \mathrm{mmol})$ and acetonitrile $(1 \mathrm{~mL})$ under a nitrogen atmosphere. $\mathrm{KPF}_{6}(96 \mathrm{mg}, 0.52 \mathrm{mmol})$ was added in one portion and the suspension was stirred vigorously for 4 days at rt. The fine white precipitate was filtered quickly in air and washed with dry acetonitrile $(2 \times 1 \mathrm{~mL})$. The filtrate and washings were combined, solvent removed by rotary evaporation then in vacuo. The product was dried at $60{ }^{\circ} \mathrm{C}$ at $0.01 \mathrm{mmHg}$ for $72 \mathrm{~h}$ to give a clear crystalline solid in $99 \%$ yield (145 mg, $0.42 \mathrm{mmol}) . \mathrm{mp}$ $=64-66{ }^{\circ} \mathrm{C} ;{ }^{1} \mathrm{H}$ NMR $\left(300 \mathrm{MHz}, \mathrm{CD}_{3} \mathrm{CN}\right) \delta 8.46(\mathrm{~s}, 1 \mathrm{H}), 7.36(\mathrm{~s}$, $2 \mathrm{H}), 6.78(\mathrm{bs}, 1 \mathrm{H}, \mathrm{NH}), 4.80(\mathrm{~s}, 2 \mathrm{H}), 3.87(\mathrm{~s}, 3 \mathrm{H}), 3.21(\mathrm{q}, J=7.0$ $\mathrm{Hz}, 2 \mathrm{H}), 1.60-1.30(\mathrm{~m}, 4 \mathrm{H}), 0.93(\mathrm{t}, J=7.0 \mathrm{~Hz}, 3 \mathrm{H}) .{ }^{13} \mathrm{C}(75 \mathrm{MHz})$ $\delta 165.87,138.66,125.15,124.69,52.36,40.68,37.51,32.53,21.14$, 14.55. ${ }^{19} \mathrm{~F}(254 \mathrm{MHz}) \delta-72.46\left(\mathrm{~d}, J_{\mathrm{P}-\mathrm{F}}=707 \mathrm{~Hz}, \mathrm{PF}_{6}{ }^{-}\right)$; $\mathrm{MS}$ (ESI): $m / z, 196.1\left[\mathrm{M}-\mathrm{PF}_{6}{ }^{-}\right]^{+} ; \mathrm{MS}$ (ESI): $m / z, 144.9\left[\mathrm{PF}_{6}{ }^{-}\right]$.

\section{3-Methyl-1-( $N$-butyl- $N$-methylcarbamoylmethyl)- imidazolium $\mathrm{PF}_{6}(9 \mathrm{i})$}

This compound was prepared analogously to 9a using 3-methyl1-( $N$-butyl- $N$-methylcarbamoylmethyl)imidazolium bromide $\mathbf{7 i}$ (265 mg, $0.91 \mathrm{mmol}, 1: 1.3$ mixture of isomers) and $\mathrm{KPF}_{6}(185 \mathrm{mg}$, $1.0 \mathrm{mmol})$ to give a crystalline solid in $70 \%$ yield $(225 \mathrm{mg}, 0.63$ mmol, $1: 1.3$ mixture of isomers). $\mathrm{mp}=62-64{ }^{\circ} \mathrm{C} ; *$ denotes both isomers. ${ }^{1} \mathrm{H}$ NMR $\left(300 \mathrm{MHz}, \mathrm{CD}_{3} \mathrm{CN}\right) \delta 8.42(\mathrm{~s}, 1 \mathrm{H}$, minor), 8.40 (s, 1H, major), 7.40-7.30 (m, 2H*), $5.06(\mathrm{~s}, 2 \mathrm{H}$, major), $5.03(\mathrm{~s}, 2 \mathrm{H}$, minor), $3.88\left(\mathrm{~s}, 3 \mathrm{H}^{*}\right), 3.37$ (t, $J=7.0 \mathrm{~Hz}, 2 \mathrm{H}$, major), 3.28 (t, $J=$ $7.0 \mathrm{~Hz}, 2 \mathrm{H}$, minor), 3.00 (s, 3H, major), 2.92 (s, 3H, minor), $1.70-1.25\left(\mathrm{~m}, 4 \mathrm{H}^{*}\right), 0.99(\mathrm{t}, J=7.0 \mathrm{~Hz}, 3 \mathrm{H}$, minor), $0.93(\mathrm{t}, J=$ $7.0 \mathrm{~Hz}, 3 \mathrm{H}$, major); ${ }^{13} \mathrm{C}(75 \mathrm{MHz}) \delta 165.75$ (major), 165.48 (minor), 138.93 (minor), 138.85 (major), 125.51 (minor), 125.45 (major), 124.42*, 51.86 (major), 51.61 (minor), 50.00 (minor), 49.18 (major), 37.50*, 35.05 (major), 34.59 (minor), 31.28 (minor), 30.36 (major), $21.11^{*}, 14.69$ (major), 14.65 (minor). ${ }^{19} \mathrm{~F}$ (254 $\mathrm{MHz}) \delta-72.38\left(\mathrm{~d}, J_{\mathrm{P}-\mathrm{F}}=710 \mathrm{~Hz}, \mathrm{PF}_{6}{ }^{-}\right)$; MS (ESI): $\mathrm{m} / z, 210.2$ $\left[\mathrm{M}-\mathrm{PF}_{6}{ }^{-}\right]^{+} ; \mathrm{MS}$ (ESI): $\mathrm{m} / z, 144.9\left[\mathrm{PF}_{6}{ }^{-}\right]$

\section{3-Methyl-1-( $N, N$-diethylcarbamoylmethyl)imidazolium $\mathrm{PF}_{6}(\mathbf{9 j})$}

This compound was prepared analogously to 9a using 3-methyl1-(N,N-diethylcarbamoylmethyl)imidazolium bromide $7 \mathbf{j}$ ( $828 \mathrm{mg}$, $3.0 \mathrm{mmol})$ and $\mathrm{KPF}_{6}(607 \mathrm{mg}, 3.3 \mathrm{mmol})$ to give a crystalline solid in $66 \%$ yield $(0.68 \mathrm{~g}, 2.0 \mathrm{mmol}) . \mathrm{mp}=64-66{ }^{\circ} \mathrm{C} ;{ }^{1} \mathrm{H}$ NMR $(300$ $\left.\mathrm{MHz}, \mathrm{CD}_{3} \mathrm{CN}\right) \delta 8.43(\mathrm{~s}, 1 \mathrm{H}), 7.33(\mathrm{~s}, 2 \mathrm{H}), 5.04(\mathrm{~s}, 2 \mathrm{H}), 3.88(\mathrm{~s}$, $3 \mathrm{H}), 3.37(\mathrm{q}, J=7.0 \mathrm{~Hz}, 2 \mathrm{H}), 3.34(\mathrm{q}, J=7.0 \mathrm{~Hz}, 2 \mathrm{H}), 1.23(\mathrm{t}, J$ $=7.0 \mathrm{~Hz}, 3 \mathrm{H}), 1.10(\mathrm{t}, J=7.0 \mathrm{~Hz}, 3 \mathrm{H}) ;{ }^{13} \mathrm{C}(75 \mathrm{MHz}) \delta 164.80$, 138.85, 125.47, 124.34, 51.71, 42.50, 42.00, 37.54, 14.65, 13.55; ${ }^{19} \mathrm{~F}(254 \mathrm{MHz}) \delta-72.8\left(\mathrm{~d}, J_{\mathrm{P}-\mathrm{F}}=707 \mathrm{~Hz}, \mathrm{PF}_{6}{ }^{-}\right)$; MS (ESI): $\mathrm{m} / z$, $196.1\left[\mathrm{M}-\mathrm{PF}_{6}{ }^{-}\right]^{+} ; \mathrm{MS}(\mathrm{ESI}): \mathrm{m} / z, 144.9\left[\mathrm{PF}_{6}{ }^{-}\right]$.

\section{3-Methyl-1-(methoxycarbonylmethyl)imidazolium $\mathrm{NTf}_{2}$ (10a)}

A flask was charged with 3-methyl-1-(methoxycarbonylmethyl)imidazolium bromide $7 \mathbf{a}(702 \mathrm{mg}, 3.0 \mathrm{mmol})$ and distilled water (2 $\mathrm{mL})$. $\mathrm{LiNTf}_{2}(947 \mathrm{mg}, 3.3 \mathrm{mmol})$ in distilled water $(1 \mathrm{~mL})$ was added in one portion and the suspension was stirred vigorously for $4 \mathrm{~h}$ at $\mathrm{rt}$. The top aqueous layer was removed, the IL washed with water $(3 \times 1 \mathrm{~mL})$ then the solvent removed in vacuo. The product was dried at $60^{\circ} \mathrm{C}$ at $0.01 \mathrm{mmHg}$ for $72 \mathrm{~h}$ to give a clear viscous oil in $93 \%$ yield $(1.21 \mathrm{~g}, 2.8 \mathrm{mmol}) .{ }^{1} \mathrm{H}$ NMR $\left(300 \mathrm{MHz}, \mathrm{CD}_{3} \mathrm{CN}\right) \delta$ $8.49(\mathrm{~s}, 1 \mathrm{H}), 7.39(\mathrm{bs}, 2 \mathrm{H}), 4.99(\mathrm{~s}, 2 \mathrm{H}), 3.88(\mathrm{~s}, 3 \mathrm{H}), 3.79(\mathrm{~s}, 3 \mathrm{H})$. ${ }^{13} \mathrm{C}(75 \mathrm{MHz}) \delta 168.23,138.59,125.22,125.09,121.39(\mathrm{q}, J=320$ $\left.\mathrm{Hz}, \mathrm{CF}_{3}\right), 54.31,51.19,37.64 .{ }^{19} \mathrm{~F}(254 \mathrm{MHz}) \delta-80.15\left(\mathrm{CF}_{3}\right) . \mathrm{MS}$ (ESI): $m / z, 155.1\left[\mathrm{M}-\mathrm{NTf}_{2}{ }^{-}\right]^{+}$; MS (ESI): $m / z, 279.9\left[\mathrm{NTf}_{2}{ }^{-}\right]$.

\section{3-Methyl-1-(ethoxycarbonylmethyl)imidazolium NTf $_{2}$ (10b)}

This compound was prepared analogously to 10a using 3-methyl1-(ethoxycarbonylmethyl)imidazolium bromide $7 \mathbf{b}(0.53 \mathrm{~g}, 2.1$ $\mathrm{mmol})$ and $\operatorname{LiNTf}_{2}(0.60 \mathrm{~g}, 2.1 \mathrm{mmol})$ to give a clear viscous oil in $90 \%$ yield $(0.85 \mathrm{~g}, 1.9 \mathrm{mmol}) .{ }^{1} \mathrm{H}$ NMR $\left(300 \mathrm{MHz}, \mathrm{CD}_{3} \mathrm{CN}\right) \delta 8.46$ (s, 1H), 7.39 (s, 2H), $4.96(\mathrm{~s}, 2 \mathrm{H}), 4.26(\mathrm{q}, J=7.0 \mathrm{~Hz}, 2 \mathrm{H}), 3.88$ $(\mathrm{s}, 3 \mathrm{H}), 1.29(\mathrm{t}, J=7.0 \mathrm{~Hz}, 3 \mathrm{H}) .{ }^{13} \mathrm{C}(75 \mathrm{MHz}) \delta 167.70,138.66$, $125.19,124.98,123.53$ (q, $J=320 \mathrm{~Hz}, \mathrm{CF}_{3}$ ), 63.98, 51.33, 37.64, 14.81. ${ }^{19} \mathrm{~F}(254 \mathrm{MHz}) \delta-80.05\left(\mathrm{CF}_{3}\right)$. MS (ESI): $\mathrm{m} / \mathrm{z}, 169.1$ [M-NTf $\left.{ }_{2}^{-}\right]^{+}$; MS (ESI): $m / z, 279.9\left[\mathrm{NTf}_{2}{ }^{-}\right]$.

\section{3-Methyl-1-(propoxycarbonylmethyl)imidazolium $\mathrm{NTf}_{2}$ (10c)}

This compound was prepared analogously to 10a using 3-methyl1-(propoxycarbonylmethyl)imidazolium bromide 7c $(0.95 \mathrm{~g}, 3.6$ mmol) and $\operatorname{LiNTf}_{2}(1.15 \mathrm{~g}, 4.0 \mathrm{mmol})$ to give a clear viscous oil in $92 \%$ yield (1.55 g, $3.4 \mathrm{mmol}) .{ }^{1} \mathrm{H}$ NMR $\left(300 \mathrm{MHz}, \mathrm{CD}_{3} \mathrm{CN}\right) \delta 8.49$ $(\mathrm{s}, 1 \mathrm{H}), 7.39(\mathrm{~s}, 2 \mathrm{H}), 4.99(\mathrm{~s}, 2 \mathrm{H}), 4.17(\mathrm{t}, J=7.0 \mathrm{~Hz}, 2 \mathrm{H}), 3.87(\mathrm{~s}$, $3 \mathrm{H}), 1.68(\mathrm{tq}, J=7.0,7.0 \mathrm{~Hz}, 2 \mathrm{H}), 0.95(\mathrm{t}, J=7.0 \mathrm{~Hz}, 3 \mathrm{H}) .{ }^{13} \mathrm{C}$ (75 MHz) $\delta 167.89,138.82,125.27,125.02,121.44(\mathrm{q}, J=320 \mathrm{~Hz}$, $\left.\mathrm{CF}_{3}\right), 69.44,51.32,37.63,23.03,11.03 .{ }^{19} \mathrm{~F}(254 \mathrm{MHz}) \delta-80.06$ $\left(\mathrm{CF}_{3}\right)$. MS (ESI): $\mathrm{m} / z, 183.1\left[\mathrm{M}-\mathrm{NTf}_{2}{ }^{-}\right]^{+}$; MS (ESI): $\mathrm{m} / z, 279.9$ $\left[\mathrm{NTf}_{2}-\right.$. 


\section{3-Methyl-1-(hexoxycarbonylmethyl)imidazolium NTf $_{2}$ (10d)}

This compound was prepared analogously to 10a using 3-methyl1-(hexoxycarbonylmethyl)imidazolium bromide 7d $(680 \mathrm{mg}, 2.0$ mmol) and $\operatorname{LiNTf}_{2}(637 \mathrm{mg}, 2.2 \mathrm{mmol})$ to give a clear viscous oil in $89 \%$ yield $(0.90 \mathrm{~g}, 1.8 \mathrm{mmol}) .{ }^{1} \mathrm{H}$ NMR $\left(300 \mathrm{MHz}, \mathrm{CD}_{3} \mathrm{CN}\right) \delta$ $8.47(\mathrm{~s}, 1 \mathrm{H}), 7.39(\mathrm{~s}, 2 \mathrm{H}), 4.97(\mathrm{~s}, 2 \mathrm{H}), 4.19(\mathrm{t}, J=7.0 \mathrm{~Hz}, 2 \mathrm{H})$, $3.87(\mathrm{~s}, 3 \mathrm{H}), 1.70-1.60(\mathrm{~m}, 2 \mathrm{H}), 1.40-1.30(\mathrm{~m}, 6 \mathrm{H}), 0.90(\mathrm{t}, J=7.0$ $\mathrm{Hz}, 3 \mathrm{H}) .{ }^{13} \mathrm{C}(75 \mathrm{MHz}) \delta 167.74,138.60,125.16,124.97,121.39$ $\left(\mathrm{q}, J=320 \mathrm{~Hz}, \mathrm{CF}_{3}\right), 67.90,51.30,37.65,32.53,29.55,26.57$, $23.70,14.74 .{ }^{19} \mathrm{~F}(254 \mathrm{MHz}) \delta-80.20\left(\mathrm{CF}_{3}\right)$. MS (ESI): $\mathrm{m} / z, 225.2$ [M-NTf $\left.2^{-}\right]^{+} ; \mathrm{MS}$ (ESI): $\mathrm{m} / z, 279.9\left[\mathrm{NTf}_{2}{ }^{-}\right]$.

\section{3-Methyl-1-(octoxycarbonylmethyl)imidazolium $\mathrm{NTf}_{2}$ (10g)}

This compound was prepared analogously to 10a using 3-methyl1-(octoxycarbonylmethyl)imidazolium bromide $7 \mathrm{~g}$ (548 mg, 1.64 mmol) and $\operatorname{LiNTf}_{2}(520 \mathrm{mg}, 1.81 \mathrm{mmol})$ to give a clear viscous oil in $93 \%$ yield $(0.81 \mathrm{~g}, 1.52 \mathrm{mmol}) .{ }^{1} \mathrm{H}$ NMR $\left(300 \mathrm{MHz}, \mathrm{CD}_{3} \mathrm{CN}\right) \delta$ $8.48(\mathrm{~s}, 1 \mathrm{H}), 7.39(\mathrm{~s}, 2 \mathrm{H}), 4.97(\mathrm{~s}, 2 \mathrm{H}), 4.20(\mathrm{t}, J=7.0 \mathrm{~Hz}, 2 \mathrm{H})$, $3.88(\mathrm{~s}, 3 \mathrm{H}), 1.70-1.60(\mathrm{~m}, 2 \mathrm{H}), 1.40-1.20(\mathrm{~m}, 10 \mathrm{H}), 0.90(\mathrm{t}, J=$ $7.0 \mathrm{~Hz}, 3 \mathrm{H}) .{ }^{13} \mathrm{C}(75 \mathrm{MHz}) \delta 167.76,138.72,125.21,124.27$, $121.20\left(\mathrm{q}, J=320 \mathrm{~Hz}, \mathrm{CF}_{3}\right), 67.95,51.28,37.60,33.06,30.43$, $30.40,29.62,26.96,23.89,14.95 .{ }^{19} \mathrm{~F}(254 \mathrm{MHz}) \delta-80.05\left(\mathrm{CF}_{3}\right)$; MS (ESI): $\mathrm{m} / z, 253.3\left[\mathrm{M}-\mathrm{NTf}_{2}{ }^{-}\right]^{+} ; \mathrm{MS}$ (ESI): $\mathrm{m} / \mathrm{z}, 279.9$ $\left[\mathrm{NTf}_{2}{ }^{-}\right]$.

\section{3-Methyl-1-( $N$-butyl- $N$-methylcarbamoylmethyl)- imidazolium NTf $_{2}(10 i)$}

This compound was prepared analogously to 10a using 3-methyl1 -( $N$-butyl- $N$-methylcarbamoylmethyl)imidazolium bromide $\mathbf{7 i}$ (302 mg, 1.04 mmol, $1: 1.3$ mixture of isomers) and $\operatorname{LiNTf}_{2}$ (329 $\mathrm{mg}, 1.15 \mathrm{mmol})$ to give a clear viscous oil in $80 \%$ yield $(410 \mathrm{mg}$, 0.84 mmol, $1: 1.3$ mixture of isomers). ${ }^{*}$ denotes both isomers. ${ }^{1} \mathrm{H}$ NMR $\left(300 \mathrm{MHz}, \mathrm{CD}_{3} \mathrm{CN}\right) \delta 8.42(\mathrm{~s}, 1 \mathrm{H}$, minor), $8.40(\mathrm{~s}, 1 \mathrm{H}$ major), 7.40-7.30 (m, 2H*), $5.06(\mathrm{~s}, 2 \mathrm{H}$, minor), $5.02(\mathrm{~s}, 2 \mathrm{H}$ major), $3.88\left(\mathrm{~s}, 3 \mathrm{H}^{*}\right), 3.37(\mathrm{t}, J=7.0 \mathrm{~Hz}, 2 \mathrm{H}$, major), $3.28(\mathrm{t}, J=$ $7.0 \mathrm{~Hz}, 2 \mathrm{H}$, minor), 3.00 (s, 3H, major), 2.92 (s, 3H, minor), $1.70-1.25\left(\mathrm{~m}, 4 \mathrm{H}^{*}\right), 0.99(\mathrm{t}, J=7.0 \mathrm{~Hz}, 3 \mathrm{H}$, minor), $0.93(\mathrm{t}, J=$ $7.0 \mathrm{~Hz}, 3 \mathrm{H}$, major). ${ }^{13} \mathrm{C}(75 \mathrm{MHz}) \delta 165.72$ (major), 165.47 (minor), 139.01 (minor), 138.93 (major), 125.55 (minor), 125.48 (major), $124.38 *, 121.42 *$ (q, $J=320 \mathrm{~Hz}, \mathrm{CF}_{3}$ ), 51.90 (major), 51.65 (minor), 50.07 (minor), 49.24 (major), 37.49*, 35.07 (major), 34.62 (minor), 31.29 (minor), 30.36 (major), 21.10*, 14.67 (major), 14.61 (minor). ${ }^{19} \mathrm{~F}(254 \mathrm{MHz}) \delta-79.90\left(\mathrm{CF}_{3}\right)$; $\mathrm{MS}(\mathrm{ESI}): \mathrm{m} / z$, $210.2\left[\mathrm{M}-\mathrm{NTf}_{2}{ }^{-}\right]^{+}$; MS (ESI): $\mathrm{m} / z, 279.9\left[\mathrm{NTf}_{2}{ }^{-}\right]$.

\section{3-Methyl-1-( $N, N$-diethylcarbamoylmethyl)imidazolium $\operatorname{NTf}_{2}(\mathbf{1 0 j})$}

This compound was prepared analogously to 10a using 3-methyl1-( $N, N$-diethylcarbamoylmethyl)imidazolium bromide $\mathbf{7 j}$ ( $828 \mathrm{mg}$, $3.0 \mathrm{mmol})$ and $\operatorname{LiNTf}_{2}(947 \mathrm{mg}, 3.3 \mathrm{mmol})$ to give a crystalline solid in $83 \%$ yield $(1.18 \mathrm{~g}, 2.48 \mathrm{mmol}) . \mathrm{mp}=43-45^{\circ} \mathrm{C} ;{ }^{1} \mathrm{H}$ NMR $\left(300 \mathrm{MHz}, \mathrm{CD}_{3} \mathrm{CN}\right) \delta 8.47(\mathrm{~s}, 1 \mathrm{H}), 7.34(\mathrm{~s}, 2 \mathrm{H}), 5.06(\mathrm{~s}, 2 \mathrm{H}), 3.88$ $(\mathrm{s}, 3 \mathrm{H}), 3.37(\mathrm{q}, J=7.0 \mathrm{~Hz}, 2 \mathrm{H}), 3.34(\mathrm{q}, J=7.0 \mathrm{~Hz}, 2 \mathrm{H}), 1.23(\mathrm{t}$, $J=7.0 \mathrm{~Hz}, 3 \mathrm{H}), 1.10(\mathrm{t}, J=7.0 \mathrm{~Hz}, 3 \mathrm{H}) .{ }^{13} \mathrm{C}(75 \mathrm{MHz}) \delta 164.81$, $138.89,125.47,124.33,121.39$ (q, $\left.J=320 \mathrm{~Hz}, \mathrm{CF}_{3}\right), 51.72,42.51$, $42.00,37.53,14.65,13.55 .{ }^{19} \mathrm{~F}(254 \mathrm{MHz}) \delta-80.03\left(\mathrm{CF}_{3}\right)$; MS (ESI): $m / z, 196.1\left[\mathrm{M}-\mathrm{NTf}_{2}{ }^{-}\right]^{+}$; MS (ESI): $\mathrm{m} / z, 279.9\left[\mathrm{NTf}_{2}{ }^{-}\right]$.

\section{3-Methyl-1-(ethoxycarbonylmethyl)imidazolium $\mathrm{N}(\mathrm{CN})_{2}$ (11b)}

A dry flask was charged with 3-methyl-1-(ethoxycarbonylmethyl)imidazolium bromide $(7 \mathbf{b})(1.50 \mathrm{~g}, 6.0 \mathrm{mmol})$ and acetonitrile $(3$ $\mathrm{mL}$ ) under a nitrogen atmosphere. NaNCNCN (641 mg, $7.2 \mathrm{mmol}$ ) was added in one portion and the suspension was stirred vigorously for 4 days at rt. The fine white precipitate was filtered quickly in air and washed with dry acetonitrile $(2 \times 1 \mathrm{~mL})$. The filtrate and washings were combined, solvent removed by rotary evaporation then in vacuo. The product was dried at $60^{\circ} \mathrm{C}$ at $0.01 \mathrm{mmHg}$ for 72 $\mathrm{h}$ to give a clear viscous hygroscopic oil in $96 \%$ yield $(1.35 \mathrm{~g}, 5.73$ mmol). ${ }^{1} \mathrm{H}$ NMR $\left(300 \mathrm{MHz}, \mathrm{CD}_{3} \mathrm{CN}\right) \delta 9.06(\mathrm{~s}, 1 \mathrm{H}), 7.53(\mathrm{~s}, 1 \mathrm{H})$, $7.45(\mathrm{~s}, 1 \mathrm{H}), 5.18(\mathrm{~s}, 2 \mathrm{H}), 4.25(\mathrm{q}, J=7.0 \mathrm{~Hz}, 2 \mathrm{H}), 3.92(\mathrm{~s}, 3 \mathrm{H})$, $1.29(\mathrm{t}, J=7.0 \mathrm{~Hz}, 3 \mathrm{H}) .{ }^{13} \mathrm{C}(75 \mathrm{MHz}) \delta 167.90,138.99,125.02$, $124.64,63.67,51.26,37.53,14.77$. Peaks for $\mathrm{NCNCN}^{-}$not cited. MS (ESI): $\mathrm{m} / z, 169.1\left[\mathrm{M}-\mathrm{NCNCN}^{-}\right]^{+}$; MS (ESI): $\mathrm{m} / z, 66.0$ $\left[\mathrm{NCNCN}^{-}\right]$.

\section{3-Methyl-1-( $N$-butyl- $N$-methylcarbamoylmethyl)- imidazolium $\mathrm{N}(\mathrm{CN})_{2}(11 i)$}

This compound was prepared analogously to $\mathbf{1 1 b}$ using 3-methyl1-( $N$-butyl- $N$-methylcarbamoylmethyl)imidazolium bromide $\mathbf{7 i}$ (208 mg, $0.71 \mathrm{mmol}, 1: 1.3$ mixture of isomers) and NaNCNCN (77 $\mathrm{mg}, 0.86 \mathrm{mmol}$ ) to give a clear viscous hygroscopic oil in $96 \%$ yield (189 mg, $0.68 \mathrm{mmol}, 1: 1.3$ mixture of isomers). $*$ denotes both isomers. ${ }^{1} \mathrm{H}$ NMR $\left(300 \mathrm{MHz}, \mathrm{CD}_{3} \mathrm{CN}\right) \delta 8.75$ (s, $1 \mathrm{H}$, minor), 8.71 (s, 1H, major), 7.50-7.35 (m, 2H*), 5.20 (s, 2H, major), $5.18(\mathrm{~s}, 2 \mathrm{H}$, minor), 3.90 (s, $\left.3 \mathrm{H}^{*}\right), 3.37$ (t, $J=7.0 \mathrm{~Hz}, 2 \mathrm{H}$, major), 3.30 (t, $J=$ $7.0 \mathrm{~Hz}, 2 \mathrm{H}$, minor), 3.02 ( $\mathrm{s}, 3 \mathrm{H}$, major), 2.92 (s, 3H, minor), $1.70-1.25\left(\mathrm{~m}, 4 \mathrm{H}^{*}\right), 0.99(\mathrm{t}, J=7.0 \mathrm{~Hz}, 3 \mathrm{H}$, minor), $0.93(\mathrm{t}, J=$ $7.0 \mathrm{~Hz}, 3 \mathrm{H}$, major). ${ }^{13} \mathrm{C}(75 \mathrm{MHz}) \delta 165.85$ (major), 165.54 (minor), 138.99 (minor), 138.85 (major), 125.19 (minor), 125.11 (major), 123.94*, 51.78 (major), 51.43 (minor), 49.78 (minor), 48.75 (major), 37.29*, 35.03 (major), 34.36 (minor), 31.02 (minor), 30.09 (major), 20.85 (minor), 20.77 (major), 14.41*. Peaks for $\mathrm{NCNCN}^{-}$not cited. MS (ESI): $\mathrm{m} / z, 210.2\left[\mathrm{M}-\mathrm{NCNCN}^{-}\right]^{+}$; MS (ESI): $m / z, 66.0\left[\mathrm{NCNCN}^{-}\right]$.

\section{Butyl bromoacetate (12d) ${ }^{42}$}

To a stirred solution of triethylamine $(41.6 \mathrm{~mL}, 300 \mathrm{mmol})$, butan1-ol (18.3 mL, $14.82 \mathrm{~g}, 200 \mathrm{mmol})$ and dichloromethane $(300 \mathrm{~mL})$ at $-78{ }^{\circ} \mathrm{C}$ under a nitrogen atmosphere was added dropwise bromoacetyl bromide ( $17.4 \mathrm{~mL}, 40.37 \mathrm{~g}, 200 \mathrm{mmol})$. After stirring at $-78{ }^{\circ} \mathrm{C}$ for $3 \mathrm{~h}$ the reaction mixture was allowed to warm up to $-20^{\circ} \mathrm{C}$ and quenched by addition of water $(50 \mathrm{~mL})$. The organic phase was washed with distilled water $(3 \times 50 \mathrm{~mL})$, saturated ammonium chloride $(3 \times 50 \mathrm{~mL})$, saturated sodium bicarbonate $(3$ $\times 50 \mathrm{~mL})$ and brine $(2 \times 50 \mathrm{~mL})$ then dried over magnesium sulfate, filtered and solvents removed via rotary evaporation. The crude product ( $28 \mathrm{~g}$, clean by ${ }^{1} \mathrm{H}$ NMR) was distilled to give a pale yellow oil in $59 \%$ yield $(23.1 \mathrm{~g}, 118 \mathrm{mmol}) .{ }^{1} \mathrm{H}$ NMR $(300 \mathrm{MHz}$, $\left.\mathrm{CDCl}_{3}\right) \delta 4.17(\mathrm{t}, J=7.0 \mathrm{~Hz}, 2 \mathrm{H}), 3.81(\mathrm{~s}, 3 \mathrm{H}), 1.64(\mathrm{tt}, J=7.0$, $7.0 \mathrm{~Hz}, 2 \mathrm{H}), 1.40(\mathrm{tt}, J=7.0,7.0 \mathrm{~Hz}, 2 \mathrm{H}), 0.93(\mathrm{t}, J=7.0 \mathrm{~Hz}, 3 \mathrm{H})$ ${ }^{13} \mathrm{C}(75 \mathrm{MHz}) \delta .167 .17,66.01,30.33,25.77,18.87,13.49$.

\section{Pentylbromoacetate (12e) $)^{42,43}$}

This compound was prepared analogously to butylbromoacetate using pentan-1-ol $(21.7 \mathrm{~mL}, 17.6 \mathrm{~g}, 200 \mathrm{mmol})$ to give a pale yellow oil in $72 \%$ yield $(29.9 \mathrm{~g}, 143 \mathrm{mmol}) .{ }^{1} \mathrm{H}$ NMR $(300 \mathrm{MHz}$, $\left.\mathrm{CDCl}_{3}\right) \delta 4.16(\mathrm{t}, J=7.0 \mathrm{~Hz}, 2 \mathrm{H}), 3.81(\mathrm{~s}, 3 \mathrm{H}), 1.64(\mathrm{tt}, J=7.0$, $7.0 \mathrm{~Hz}, 2 \mathrm{H}), 1.45-1.25(\mathrm{~m}, 4 \mathrm{H}), 0.89$ (t, $J=7.0 \mathrm{~Hz}, 3 \mathrm{H}) .{ }^{13} \mathrm{C}(75$ MHz) $\delta .167 .16,66.28,27.99,27.76,25.77,22.12,13.79$.

\section{Hexylbromoacetate (12f)}

This compound was prepared analogously to butylbromoacetate using triethylamine $(20.8 \mathrm{~mL}, 150 \mathrm{mmol})$, hexan-1-ol $(12.4 \mathrm{~mL}$, $10.2 \mathrm{~g}, 100 \mathrm{mmol})$, dichloromethane $(200 \mathrm{~mL})$ and bromoacetyl bromide $(8.7 \mathrm{~mL}, 20.2 \mathrm{~g}, 100 \mathrm{mmol})$ to give a crude product $(21.6$ $\mathrm{g})$ which was distilled to give a colourless oil in $65 \%$ yield $(14.5 \mathrm{~g}$, $65 \mathrm{mmol}) .{ }^{1} \mathrm{H}$ NMR $\left(300 \mathrm{MHz}, \mathrm{CDCl}_{3}\right) \delta 4.17(\mathrm{t}, J=7.0 \mathrm{~Hz}, 2 \mathrm{H})$, $3.82(\mathrm{~s}, 3 \mathrm{H}), 1.64(\mathrm{tt}, J=7.0,7.0 \mathrm{~Hz}, 2 \mathrm{H}), 1.40-1.20(\mathrm{~m}, 6 \mathrm{H}), 0.89$ $(\mathrm{t}, J=7.0 \mathrm{~Hz}, 3 \mathrm{H}) .{ }^{13} \mathrm{C}(75 \mathrm{MHz}) \delta .167 .20,66.34,31.24,28.28$, $25.77,25.30,22.38,13.84$. NMR data in agreement with literature. ${ }^{44}$ 


\section{Octylbromoacetate (12g)}

This compound was prepared analogously to butylbromoacetate using triethylamine $(20.8 \mathrm{~mL}, 150 \mathrm{mmol})$, octan-1-ol $(15.8 \mathrm{~mL}$, $13.0 \mathrm{~g}, 100 \mathrm{mmol})$, dichloromethane $(200 \mathrm{~mL})$ and bromoacetyl bromide $(8.7 \mathrm{~mL}, 20.2 \mathrm{~g}, 100 \mathrm{mmol})$ to give a crude product (18.7 g) which was distilled to give a colourless oil in $24 \%$ yield $(6.0 \mathrm{~g}$, $24 \mathrm{mmol}$ ). ${ }^{1} \mathrm{H}$ NMR $\left(300 \mathrm{MHz}, \mathrm{CDCl}_{3} \delta 4.16(\mathrm{t}, J=7.0 \mathrm{~Hz}, 2 \mathrm{H})\right.$, $3.82(\mathrm{~s}, 3 \mathrm{H}), 1.64(\mathrm{tt}, J=7.0,7.0 \mathrm{~Hz}, 2 \mathrm{H}), 1.40-1.20(\mathrm{~m}, 10 \mathrm{H})$, $0.88(\mathrm{t}, J=7.0 \mathrm{~Hz}, 3 \mathrm{H}) .{ }^{13} \mathrm{C}(75 \mathrm{MHz}) \delta 167.13,66.27,31.62$, $29.00,29.01,28.30,25.74,25.62,22.48,13.91$. NMR data in agreement with literature. ${ }^{45}$

\section{$N$-Butyl-2-bromoacetamide (12h) ${ }^{\mathbf{4 6}}$}

This compound was prepared analogously to butylbromoacetate using triethylamine $(20.8 \mathrm{~mL}, 150 \mathrm{mmol})$, butylamine $(9.8 \mathrm{~mL}, 7.3$ $\mathrm{g}, 100 \mathrm{mmol})$, dichloromethane $(200 \mathrm{~mL})$ and bromoacetyl bromide $(8.7 \mathrm{~mL}, 20.2 \mathrm{~g}, 100 \mathrm{mmol})$ to give a crude product $(18.0$ g) which was distilled to give a light brown oil, which crystallized on standing, in $39 \%$ yield $(7.5 \mathrm{~g}, 39 \mathrm{mmol}) . \mathrm{Mp}=35-37^{\circ} \mathrm{C}$. Lit. $\mathrm{Mp}=38-39{ }^{\circ} \mathrm{C} .46{ }^{1} \mathrm{H} \mathrm{NMR}\left(300 \mathrm{MHz}, \mathrm{CDCl}_{3}\right) \delta 6.50(\mathrm{bs}, 1 \mathrm{H}$, $\mathrm{NH}), 3.87(\mathrm{~s}, 2 \mathrm{H}), 3.28(\mathrm{q}, J=7.0 \mathrm{~Hz}, 2 \mathrm{H}), 1.52(\mathrm{tt}, J=7.0,7.0$ $\mathrm{Hz}, 2 \mathrm{H}), 1.37$ (tt, $J=7.0,7.0 \mathrm{~Hz}, 2 \mathrm{H}), 0.93(\mathrm{t}, J=7.0 \mathrm{~Hz}, 3 \mathrm{H}) .{ }^{13} \mathrm{C}$ (75 MHz) $\delta 165.35,39.85,31.18,29.17,19.86,13.55$.

\section{$N$-Butyl- $N$-methyl-2-bromoacetamide (12i) ${ }^{42}$}

This compound was prepared analogously to butylbromoacetate using triethylamine $(20.8 \mathrm{~mL}, 150 \mathrm{mmol}), \mathrm{N}$-methyl-butylamine $(11.8 \mathrm{~mL}, 8.72 \mathrm{~g}, 100 \mathrm{mmol})$, dichloromethane $(200 \mathrm{~mL})$ and bromoacetyl bromide $(8.7 \mathrm{~mL}, 20.2 \mathrm{~g}, 100 \mathrm{mmol})$ to give a crude product $(21.0 \mathrm{~g})$ which was distilled to give a pale yellow oil in $54 \%$ yield (11.37 g, $54 \mathrm{mmol}) .{ }^{1} \mathrm{H} \mathrm{NMR}\left(300 \mathrm{MHz}, \mathrm{CDCl}_{3}\right) \delta 3.84(\mathrm{~s}$, $2 \mathrm{H}$, minor), 3.83 (s, $2 \mathrm{H}$, major), 3.35 (t, $J=7.0 \mathrm{~Hz}, 2 \mathrm{H}$, major), 3.30 (t, $J=7.0 \mathrm{~Hz}, 2 \mathrm{H}$, minor), 3.04 (s, $3 \mathrm{H}$, major), $2.92(\mathrm{~s}, 3 \mathrm{H}$, minor), $1.65-1.25(\mathrm{~m}, 4 \mathrm{H}$, major and minor), $0.94(\mathrm{t}, J=7.0 \mathrm{~Hz}$, $3 \mathrm{H}$, minor), 0.91 (t, $J=7.0 \mathrm{~Hz}, 3 \mathrm{H}$, major). ${ }^{13} \mathrm{C}(75 \mathrm{MHz}) \delta$ $166.30,50.55,47.88,35.89,33.61,30.41,28.84,26.57,25.89$, $19.75,13.66$.

\section{$N, N$-Diethyl-2-bromoacetamide (12j)}

This compound was prepared analogously to butylbromoacetate using triethylamine $(20.8 \mathrm{~mL}, 150 \mathrm{mmol})$, diethylamine $(10.4 \mathrm{~mL}$, $7.30 \mathrm{~g}, 100 \mathrm{mmol})$, dichloromethane $(200 \mathrm{~mL})$ and bromoacetyl bromide $(8.7 \mathrm{~mL}, 20.2 \mathrm{~g}, 100 \mathrm{mmol})$ to give a crude product $(14.5$ g) which was distilled to give a pale yellow oil in $31 \%$ yield $(6.01$ g, $31 \mathrm{mmol}$ ). ${ }^{1} \mathrm{H}$ NMR (300 MHz, $\left.\mathrm{CDCl}_{3}\right) \delta 3.83(\mathrm{~s}, 2 \mathrm{H}), 3.378$ (q, $J=7.0 \mathrm{~Hz}, 2 \mathrm{H}), 3.383(\mathrm{q}, J=7.0 \mathrm{~Hz}, 2 \mathrm{H}), 1.25(\mathrm{t}, J=7.0 \mathrm{~Hz}$, $3 \mathrm{H}), 1.13(\mathrm{t}, J=7.0 \mathrm{~Hz}, 3 \mathrm{H}) .{ }^{13} \mathrm{C}(75 \mathrm{MHz}) \delta 165.65,42.78,40.36$, $26.39,14.20,12.34$. NMR data in agreement with literature. ${ }^{47}$

\section{Closed Bottle Test}

Sodium $n$-dodecyl sulfate (SDS) was used as reference substance. Solutions containing $2 \mathrm{mg} \mathrm{L}^{-1}$ of the test ionic liquids and the reference chemical as sole sources of organic carbon were prepared, separately, in previously aerated mineral medium. The solutions were then inoculated with secondary effluent collected from an activated sludge treatment plant and each well-mixed solution was carefully dispensed into a series of BOD bottles so that all the bottles were completely full. A control with inoculum, but without test chemicals was run parallel for the determination of oxygen blanks. Duplicate bottles of each series were analysed immediately for dissolved oxygen and the remaining bottles were incubated at $20{ }^{\circ} \mathrm{C} \pm 1{ }^{\circ} \mathrm{C}$ in the dark. Bottles of all series were withdrawn in duplicate for dissolved oxygen analysis over the 28 -day incubation period. The biodegradation after $n$ days was expressed as the ratio of the biochemical oxygen demand (BOD) to the chemical oxygen demand (COD) both of them expressed as $\mathrm{mg}$ $\mathrm{O}_{2} / \mathrm{mg}$ compound. The chemical oxygen demand was determined by the dichromate reflux method. ${ }^{48}$ For the calculation of the biochemical oxygen demand the determined oxygen depletions were divided by the concentration of ionic liquid.

\section{References}

1 (a) P. Wasserscheid and W. Keim, Angew. Chem., Int. Ed., 2000, 39, 3772; (b) T. Welton, Chem. Rev., 1999, 99, 2071; (c) J. D. Holbury and K. R. Seddon, Clean Prod. Process., 1999, 1, 223; (d) P. Bonhôte, A-P Dias, N. Papageorgiou, K. Kalyanasundaram and M. Grätzal, Inorg. Chem., 1996, 35, 1168.

2 (a) J. G. Huddleston, H. D. Willauer, R. P. Swatloski, A. E. Visser and R. D. Rogers, Chem. Commun., 1998, 1765; (b) L. Blanchard, D. Nancu, E. J. Bechman and J. F. Bennecke, Nature, 1999, 399, 28; (c) A. E. Visser, R. P. Swatloski, W. M. Reichert, S. T. Griffin and R. D. Rogers, Ind. Eng. Chem. Res., 2000, 39, 3596.

3 (a) P. J. Scammells, N. Gathergood and J. Ripper, PCT Int. Appl., 2002, 25 pp. WO 0216367; (b) I. Hemeon, N. W. Barnett, N. Gathergood, P. J. Scammells and R. D. Singer, Aust. J. Chem., 2004, 2, 125.

4 R. Sheldon, Chem. Commun., 2001, 23, 2399.

5 (a) W. M. Nelson, Ionic liquids: industrial applications for green chemistry, ACS Symp. Ser. 818, ed. R. D. Rogers and K. R. Seddon, 2002, pp. 30-41; (b) T. Laird, S. A. Hermitage and U. Tilstam, Org. Process Res. Dev., 2002, 6, 338; (c) R. P. Swatloski, J. D. Holbrey and R. D. Rogers, Green Chem., 2003, 5, 361.

6 M. J. Scott and M. N. Jones, Biochim. Biophys. Acta, 2000, 1508(1-2), 235.

7 (a) R. Freer and A. Curzon, NATO Sci. Ser. II: Math. Phys. Chem., 2003, 92, 129; (b) J. D. Holbury, Ionic liquids: industrial applications for green chemistry, ACS Symp. Ser. 818, ed. R. D. Rogers and K. R. Seddon, 2002, pp. 446-4458.

8 K. R. Seddon, Nat. Mater., 2003, 2(6), 363. In this efficient case methyl imidazole is converted to the ionic liquid (the hydrochloride salt of methyl imidazole), then the methyl imidazole is regenerated and recycled.

9 N. Gathergood and P. J. Scammells, Aust. J. Chem., 2002, 55, 557.

10 B. Jastorff, R. Störmann, J. Ranke, K. Mölter, F. Stock, B. Oberheitmann, W. Hoffmann, J. Hoffmann, M. Nüchter, B. Ondruschka and J. Filser, Green Chem., 2003, 5, 136.

11 Biodegradability of Surfactants, ed. D. R. Karsa and M. R. Porter, Blackie Academic \& Professional, London, 1995.

12 R. D. Swisher, Surfactant Biodegradation, 2nd edn., Surfactant Science Series Vol 18, Marcel Dekker, New York, 1987.

13 H. A. Painter, The Handbook of Environmental Chemistry, ed. O. Hutzinger, Springer-Verlag, Berlin, Germany, 1992, vol. 3F, pp. $1-88$.

14 R. A. Rapaport and W. S. Eckhoff, Environ. Toxicol. Chem., 1990, 9, 1245 .

15 (a) R. S. Boethling, Designing Safer Chemicals, ACS Symp. Ser. 640, 1996, 156; (b) P. H. Howard, R. S. Boethling, W. Stiteler, W. Meylan and J. Beauman, Sci. Total Environ., 1991, 109/110, 635; (c) R. S. Boethling, Cationic Surfactants, Surfactant Science Series Vol. 53, Marcel Dekker, New York, 1994, pp. 95-135.

16 (a) G. E. Wenter, J. McGrady, E. P. Gosselink and W. A. Cilley, Eur. Pat. Appl., 1981, 36; (b) W. E. Gledhill and V. W. Saeger, J. Ind. Microbiol., 1987, 2(2), 97; (c) J. Waters, H. H. Kleiser, M. J. How, M. D. Barratt, R. R. Birch, R. J. Fletcher, S. D. Haugh, S. G. Hales, S. J. Marshall and T. C. Pestell, Tenside, Surfactants, Deterg., 1991, 28(6), 460; (d) B. Durif-Varambon, C. Bocard, C. Gatellier and B. Sillion, Ger. Offen., 1976, DE 255890719760708.

17 For review, see 6 .

18 (a) W. McGucken, Biodegradable : detergents and the environment, $1 \mathrm{st}$ edn., 1991, Texas A\&M University Press, USA; $(b)$ Biodegradability of Surfactants, ed. D. R. Karsa and M. R. Porter, Blackie Academic and Professional, London, 1995.

19 D. S. McGuinness and K. J. Cavell, Organometallics, 2000, 19, 741.

20 (a) Y. Matsuda, H. Gotou, K. Katou, H. Matsumoto, M. Yamashita, K. Takahashi, S. Ide, K. Furuno and K. Torisu, Hetrocycles, 1991, 32(11), 
2217; (b) R. A. Jones, J. Sepulveda Arques, E. Zaballos Garcia, P. A. Bates and M. B. Hutsthouse, J. Chem. Soc., Chem. Commun., 1986, 24 1745.

21 Ethyl chloroacetate was also reacted with 1-methylimidazole to give 3-methyl-1-(ethoxycarbonylmethyl)imidazolium chloride as a viscous oil in $98 \%$ yield.

22 D. R. MacFarlane, J. Golding, S. Forsyth, M. Forsyth and G. B. Deacon, Chem. Commun., 2001, 16, 1430.

23 S. V. Dzyuba and R. A. Bartsch, Chem. Commun., 2001, 16, 1466.

24 This ratio of tautomers is derived from the condensation of $N$-methylbutylamine with bromoacetyl bromide yielding $N$-butyl- $N$-methyl2-bromoacetamide. Heating the ionic liquids $(\mathbf{7 g - 1 1 g})$ at $60{ }^{\circ} \mathrm{C}$ for $72 \mathrm{~h}$ did not affect the ratio of amide rotomers, suggesting that this ratio is the thermodynamic equilibrium.

25 Sturm tests were performed by Leeder Consulting, 192 Station St, Fairfield VIC 3078, Australia, http://www.leederconsulting.com.

26 Test Guideline 301B: Ready Biodegradability: Modified Sturm Test in OECD Guidelines for the Testing of Chemicals, 1981, Organisation for Economic Cooperation and Development (OECD), Paris.

27 OECD Chemical Group, 1993. Ready Biodegradability: Modified OECD Screening Test. Method 301 E. OECD Revised Guidelines for Tests for Ready Biodegradability, Paris, France.

28 C. G. Van Ginkel and M. Kolvenbach, Chemosphere, 1991, 23, 281

29 M. T. García, I. Ribosa, T. Guindulain, J. Sánchez-Leal and J. VivesRego, Environ. Pollut., 2001, 111, 169.

30 R. J. Larson, Residue Rev., 1983, 85, 159

31 R. J. Larson, Dev. Ind. Microbiol., 1983, 24, 425.

32 R. M. Ventullo, Appl. Environ. Microbiol., 1986, 51, 356.

33 D. M. Tubbing and W. Admiraal, Appl. Environ. Microbiol., 1991, 57, 3616.

34 (a) Jpn. Kokai Tokkyo Koho 1980 JP 55151578; (b) B. W. Kaplan, 1980 US 4201786

35 (a) K. Ikura, K. Katsuura, M. Mizuno and T. Nishibe, Jpn. Kokai Tokkyo Koho, 1979, JP 54079278; (b) P. N. Edwards, 1979, CH 608490; (c) Japan. Kokai 1974, JP 49127968; (d) P. N. Edwards Brit.
1975, GB 1408344; (e) Austrian, 1975, AT 322546; (f) Neth. Appl., 1974, NL 7304808 .

36 J. Ranke, K. Mölter, F. Stock, U. Bottin-Weber, J. Poczobutt, J. Hoffmann, B. Ondruschka, J. Filser and B. Jastorff, Ml CPS: biochem/ 0303001 .

37 J. Pernak, K. Sobaszkiewicz and I. Mirska, Green Chem., 2003, 5, 52.

38 D. L. Fredell, Cationic Surfactants, Surfactant Science Series Vol. 53, Marcel Dekker,: New York, 1994, pp. 31-60.

39 (a) N. Bodor, J. J. Kaminski and S. Selk, J. Med. Chem., 1980, 23(5) 469; (b) N. Bodor and J. J. Kaminski, J. Med Chem, 1980, 23(5), 566; (c) Bodor, R. Woods, C. Raper, P. Kearney and J. J. Kaminski, J. Med. Chem., 1980, 23(5), 474; (d) N. Bodor 1976 US 39897111; (e) N. Bodor, 1979 US 4160099.

40 Jpn. Kokai Tokkyo Koho, 1987, JP 62294603.

41 P. Wasserscheid, R. von Hal and A. Bösmann, Green Chem., 2002, 4, 400.

42 No NMR data previously reported.

43 Pentylbromoacetate has been previously synthesized by the esterification of bromoacetic acid and pentanol, Z. Zhang, H. Pan, C. Hu, F. Fu, Y. Sun, R. Willem and M. Gielen, Appl. Organomet. Chem., 1991, 5(3) 183.

44 L. Gil, Y. Han, E. E. Opas, G. A. Redan, R. Ruel, J. G. Seedor, P. C. Tyler and R. N. Young, Bioorg. Med. Chem., 1999, 7(5), 901.

45 (a) J.-F. Chollet, L. Miginiac, G. Picotin and P. Miginiac, Synth Commun., 1989, 19(11-12), 2167; (b) D. P. Arnold, J. P. Bartley and D. A. James, Aust. J. Chem., 1992, 45(8), 1191.

46 I. Kruglik and Y. G. Gololobov, J. Org. Chem. USSR (Engl. Transl.), 1978, 14, 690.

47 M. A. P. Martins and R. Rittner, Org. Magn. Reson., 1980, 14(6), 522.

48 APHA (American Public Health Association), AWWA (American Water Works Association), and WPCF (Water Pollution Contro Federation), 1985, Method 508 B. Standard Methods for the Examination of Water and Wastewater, 16th edn., Washington, pp. 532-537. 